Article

\title{
Two Scenarios for Landfills Design in Special Conditions Using the HELP Model: A Case Study in Babylon Governorate, Iraq
}

\author{
Ali Chabuk ${ }^{1,2}$, Nadhir Al-Ansari ${ }^{1, *}$ (D), Mohammad Ezz-Aldeen ${ }^{3}$, Jan Laue ${ }^{1}$, Roland Pusch ${ }^{1}$, \\ Hussain Musa Hussain ${ }^{4}$ and Sven Knutsson ${ }^{1}$ if \\ 1 Department of Civil Environmental and Natural Resources Engineering, Lulea University of Technology, \\ 97187 Lulea, Sweden; ali.chabuk@ltu.se or ali_chabuk1975@yahoo.com (A.C.); jan.laue@ltu.se (J.L.); \\ drawrite.se@gmail.com (R.P.); Sven.Knutsson@ltu.se (S.K.) \\ 2 Department of Environment Engineering, College of Engineering, University of Babylon, Babylon 51001, \\ Iraq \\ 3 Department of Dams and Water Resources Engineering, University of Mosul, Mosul 41001, Iraq; \\ mohammad.ezzaldeen@gmail.com \\ 4 Remote Sensing Center, University of Kufa, Kufa 51001, Iraq; humhudhy02@gmail.com \\ * Correspondence: nadhir.alansari@ltu.se; Tel.: +46-767768027
}

Received: 27 November 2017; Accepted: 4 January 2018; Published: 7 January 2018

\begin{abstract}
The sound design of landfills is essential in order to protect human health and the environment (air, water, and soil). The study area, Babylon Governorate, is situated in the middle of Iraq, and is distinguished by a hot climate and shallow groundwater. The governorate did not have landfill sites that meet international criteria; in addition, the groundwater depth in Babylon Governorate is commonly shallow. Previously, the most important criteria for the study area and GIS software were used to select the best sites for locating landfills in the major cities of the governorate. In this study, the Hydrologic Evaluation of Landfill Performance (HELP 3.95D) model was applied in order to ensure that there was no leakage of the leachate that results from the waste in the selected landfill sites. It is the most commonly utilized model for landfill design, and it is used to estimate water inflow through the soil layers. For the present study, to avoid groundwater pollution by leachate from a landfill site due to the shallow groundwater depth, compacted waste was placed on the surface using two height scenarios ( $2 \mathrm{~m}$ and $4 \mathrm{~m}$ ). This design was developed using the soil properties of the selected sites coupled with the weather parameters in Babylon Governorate (precipitation, temperature, solar, and evapotranspiration) for a 12-year period covering 2005 to 2016. The results from both of the suggested landfill designs showed an absence of leachate from the bottom liner.
\end{abstract}

Keywords: landfill design; HELP model; solid waste; hot climate; shallow ground water

\section{Introduction}

In most countries, especially developing countries, landfill is a common method for the disposal of municipal solid waste (MSW) [1-6]. Municipal solid waste (MSW) comprises garbage, organic waste, commercial waste, construction waste, institutional waste and industrial waste [7]. To face the growing challenge for municipal solid waste management of protecting humans and the environment, there is a need to build a prudent system of waste management. It should include selecting the best sites for landfill based on suitable criteria in the study area, adopting appropriate technology methods for waste treatment on site, and properly designing the landfill to prevent contamination of groundwater by the leachate [3,8]. Landfill is considered to be the most systematic and economic method for managing 
such waste, even when other methods are also used for waste management (e.g., reducing, recycling, incineration, and burial) [9-14]. Several countries have experienced the negative impacts on both human health and the environment (e.g., ground and surface water pollution, gas emissions, and the possibility of human suffocation due to the spontaneous combustion of landfill waste) caused by inefficient landfill management systems $[1,13,14]$. In addition, the biodegradation of landfill waste in aerobic conditions mixed with rainwater percolation through waste and the water of the waste itself produces leachate [7].

Leachate represents a primary cause of ground water pollution, with various pollutants in the liquid leachate entering through the layers of the landfill $[1,2,15]$. There are two main methods that are used in designing landfills to prevent the contamination of groundwater by leachate from landfills $[2,16]$. The first method (the old process) endeavors to disperse the leachate to flow outside the landfill into the surrounding soil and bedrock, thereby reducing the concentration effect of the leachate contaminants. This method is a natural process with a natural geologic barrier, such as clay soil, that has low permeability $[2,17]$. The second design method for modern landfills seeks to reduce any possible negative impacts on the public and the environment through the sound management of gases from landfill sites and of the leachate that results from landfill practices $[15,16]$. Thus, modern landfill design is based on principles of sound management, ongoing monitoring procedures, and finally, a reduction in the quantity of landfill leachate through using a liner system to protect soil and groundwater [15,18-20].

To prevent leachate generation or infiltration, the surface and stormwater flows should be managed through using suitable cover materials, as well as saving the material with high liquid content away from the waste management facility [21]. There are many methods for the leachate treatment such as: aerobic biological treatment (e.g., aerated lagoons and activated sludge), anaerobic biological treatment (e.g., anaerobic lagoons, reactors), physiochemical treatment (e.g., air stripping, reduction, oxidation, etc.), coagulation using several materials and advanced techniques (e.g., carbon adsorption, ion exchange) [22]. For leachate treatment, two main methods of treatment technologies can be used. These methods are physical/chemical and biological, and are usually combined to treat the leachate $[21,23]$. The biological treatment is considered the most common in modern landfills, especially in the arid or semi-arid regions [24]. The biological treatment is divided into an anaerobic and aerobic process, where the anaerobic process is used to remove the heavy metals from leachate as carbonates by precipitation. The aerobic process is used when the leachate includes fatty acids of biodegradation. In aerobic conditions, oxygen is necessary to increase the biological activity of microorganisms when the leachate contains a high concentration of biodegradable organics [23].

Leachate evaporation is considered one of the more simple and preferred methods of managing leachate through the evaporation of the leachate within lined ponds. The collected leachate, which is extracted from the waste, is transferred to ponds by the leachate collection system. The base liner layer that is used in the landfill may be similar to the liner system in the ponds [21]. Floating aerators is a common practice in the leachate pond. The floating aerators are used to reduce odors and provide some treatment through preventing the anaerobic process in the ponds, as well as increasing the evaporation of the leachate from the ponds. Periodically, it is necessary to remove the sludge from the bottom of the pond. Finally, the sludge is deposited within the landfill cell(s) or sent to an approved site by official authorities [21].

The main considerations for identifying the most suitable design for the selected landfill sites are (a) to prevent surface and groundwater pollution caused by the leachate emanating from landfill sites; (b) to eliminate, or at least minimize, the fire effects that are the result of burning the waste; (c) to manage any gas emissions from the landfill; (d) to protect the major environmental elements (air, water, soil); (e) to reduce negative environmental impact factors such as insect and rodent infestations, diseases, odors and noise; and (f) to manage the disposal of municipal solid waste in landfills in such a way as to reduce the risks to human health $[1,25]$. 
The types of landfills and liner systems are: the single-liner system (one box), the composite-liner systems (two boxes), and the double-liner system. The first type consists of a clay liner, a geosynthetic clay liner, or a clay liner with a geomembrane. The second type consists of a clay liner with a geomembrane (two boxes), and is more effective than the first type at preventing leachate from flowing through the subsoil layers. In the double-liner systems, there are two types. The first type comprises a composite liner and a single (3Box), while the second type includes two single liners and two composite liners [26].

In the current study, the selection of the most appropriate design for the selected sites in the Babylon Governorate's Qadhaas was achieved by utilizing the Hydrologic Evaluation of Landfill Performance (HELP 3.95D) model.

Landfill sites were selected for each major city in Babylon Governorate using GIS software and different methods of multi-criteria decision methods. Depending on the results of these studies, two sites for each major city were determined. The groundwater depth in Babylon Governorate is shallow. The water table in the whole area in the governorate varies in depth from $0.423 \mathrm{~m}$ to $15.97 \mathrm{~m}$ below the ground level [27]. Soil investigation was also conducted in the field at all of these sites in order to ascertain the soil properties and the groundwater depths. The results are very precise, which enables the designers to select the most suitable design for the landfill.

Over the last decade, the HELP model has become a very powerful tool for estimating the water balance for cover and bottom liner systems in municipal solid waste landfill operations. The model facilitates the calculation of the leachate rate through the soil layers, and also of the leachate head on the bottom layer at different times based on various weather data parameters (rainfall, temperature, solar radiation, evapotranspiration, etc.), especially when used in combination with a design for soil layers that works to prevent groundwater being contaminated by leachate from waste [28-30].

In the literature, many studies have used the HELP model to estimate leachate through landfill sites (e.g., $[9,20,31,32])$.

\section{Background Information}

\subsection{Study Area}

Babylon Governorate is situated in the middle of Iraq, approximately $100 \mathrm{~km}$ to the south of the Iraqi capital, Baghdad, between longitudes $44^{\circ} 2^{\prime} 43^{\prime \prime} \mathrm{E}$ and $45^{\circ} 12^{\prime} 11^{\prime \prime} \mathrm{E}$, and latitudes $32^{\circ} 5^{\prime} 41^{\prime \prime} \mathrm{N}$ and $33^{\circ} 7^{\prime} 36^{\prime \prime} \mathrm{N}$ (Figure 1). The governorate is divided administratively into five major cities. These major cities are Al-Hillah, Al-Qasim, Al-Hashimiyah, Al-Mahawil, and Al-Musayiab. The area of Babylon Governorate is $5315 \mathrm{~km}^{2}$ [33]. The population of the governorate was about 2,155,578 inhabitants in 2016, distributed throughout the five major cities according to [34].

In Iraq, open dumping of waste leads to many environmental problems, including ground and surface water contamination, insect and rodent infestation, odors, disease, and other problems. Waste is disposed of on a daily basis in Babylon Governorate by burning. This sometimes suffocates the population of the nearby cities [35].

The main reasons for the increase of production quantities of waste generally in Iraq and particularly in Babylon Governorate are: improvements to the living standards, a high population growth rate, and an increase in commercial activities [10,35].

Processes for the collection, management, and disposal of waste in Babylon Governorate are very poor. The existing sites do not comply with the scientific and environmental criteria that are usually followed in the selection of landfill sites [35]. The waste can be dealt with in different ways at different sites. There are approximately 16 waste disposal sites or dumping sites in Babylon Governorate. They are distributed throughout the cities of the governorate. Most cities in the governorate have their own waste disposal sites. Cities that do not have a landfill site transport their waste to sites in the neighboring cities [35]. 


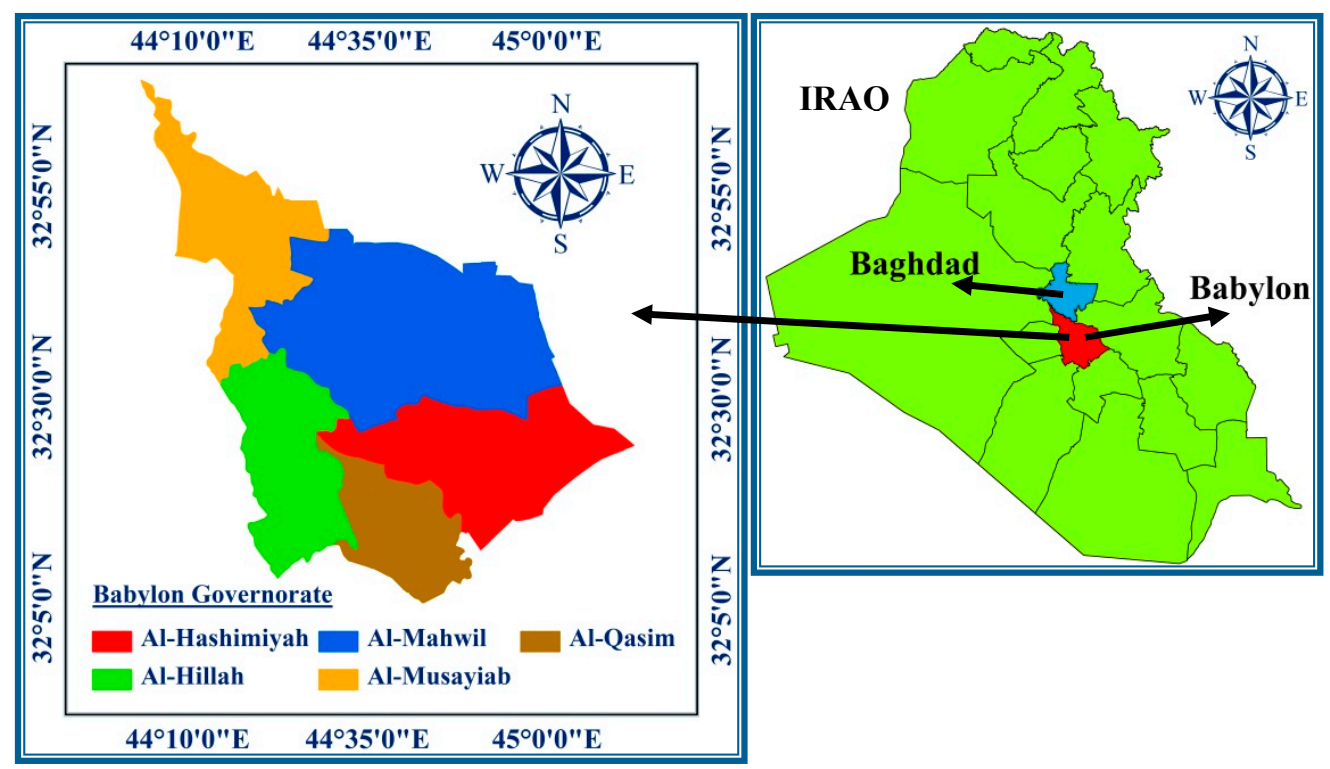

Figure 1. Babylon Governorate, Iraq.

The composition of MSW according to the Ministry of Municipalities and Public Works (2013) in Babylon is: organic waste (55\%), glass and ceramics $(5 \%)$, plastic and rubber $(8 \%)$, paper and cardboard $(5 \%)$, metals $(10 \%)$, textiles and rags $(4 \%)$, wood, bones, and straw $(6 \%)$, aluminum $(2 \%)$, and others (5\%) [36]. According to the latest study at the end of 2016, [37] suggested that $78 \%$ of the waste at Babylon could be recycled, and the remainder should be sent to landfills.

The solid waste quantity in Iraq in 2013 was 11,315,000 (tonnes) with a generation rate of solid waste of $1.4 \mathrm{~kg}$ / (capita. day) [38]. The quantity of solid waste in Babylon Governorate in 2013 was 483,221 (tonnes) [39]. The budget that was spent on waste collection processes in Babylon Governorate in 2013 was $\$ 15,894,716$ USD [35]. Based on the expected population of 3,556,966 inhabitants in the governorate by 2030, the estimated quantity of solid waste in the year 2030 will be 1,030,174 (tonnes) [35].

The expected cumulative quantity of solid waste between 2020-2030 is 8,752,506 (tonnes), according to the calculations achieved by [35]. The generation rate of solid waste in 2013 was $0.67 \mathrm{~kg}$ /(capita. day), and the annual population growth was $2.99 \%$. The average annual increment rate of solid waste generation was $1 \%$ in Babylon Governorate. The waste density in the waste disposal sites in the governorate was $450 \mathrm{~kg} / \mathrm{m}^{3}$ [39].

The value of solid waste volume in 2013 was $107,382 \mathrm{~m}^{3}$. The expected value of solid waste volume in 2030 is $2,289,275 \mathrm{~m}^{3}$, while the expected value of cumulative solid waste volume between $2020-2030$ is $19,450,013 \mathrm{~m}^{3}$ [35].

\subsection{Climate}

The governorate is situated in a desert climate that changes dramatically with the changing seasons as well as between day and night. The prevailing wind in the governorate comes from the northwest and blows throughout the year, with an annual average wind speed of $7.2 \mathrm{~km} / \mathrm{h}$. Temperatures during the summer season can reach more than $50^{\circ} \mathrm{C}$, with an average of approximately $12 \mathrm{~h}$ of sunlight/day, and usually no precipitation. The winter is cold and rainy, with approximately $6.8 \mathrm{~h} /$ day of sunlight, and although temperatures normally remain above $0{ }^{\circ} \mathrm{C}$, they can decrease below freezing during some nights. The average annual precipitation is $102 \mathrm{~mm}$, while the average annual relative humidity is $45.8 \%$ [33,40-42]. Generally, the average annual precipitation in Iraq is decreasing due to climate change. In some years, the precipitation falls in a very short period of time, causing floods [43,44]. 


\subsection{Selecting and Assessing the Candidate Sites for Landfill}

For selecting new systematic sites for landfill in Babylon Governorate, Iraq, the GIS software and methods of multi-criteria decision making (MCDM) —analytical hierarchy process (AHP), straight rank sum (SRS) and ratio scale weighting (RSW) - were used. The required maps of the most important criteria (15 criteria) were prepared using GIS software to produce the final map(s) for landfill siting. These 15 criteria are groundwater depth, urban centers, rivers, villages, soil types, elevation, agriculture, roads, land slope, land use, archaeological sites, power lines, gas pipelines, oil pipelines, and railways. Map layers of the 15 criteria were prepared using GIS software as follows: (i) reviewing the previous literature in this field for the landfill siting; (ii) preparing the digital maps in GIS software for the study area; (iii) obtaining of the sub-criteria weightings based on different requirements (e.g., literature review, expert opinion, governmental regulations, and environmental and scientific requirements); (iv) determining the weighting for each criterion using the MCDM methods; (vi) determining the final map to select the candidate sites for landfill in the governorate [45]. All of the candidate sites were selected on the final map(s) within the most suitable area category. The selected candidate sites were checked against the satellite images of Babylon Governorate (Figure 2) [46].

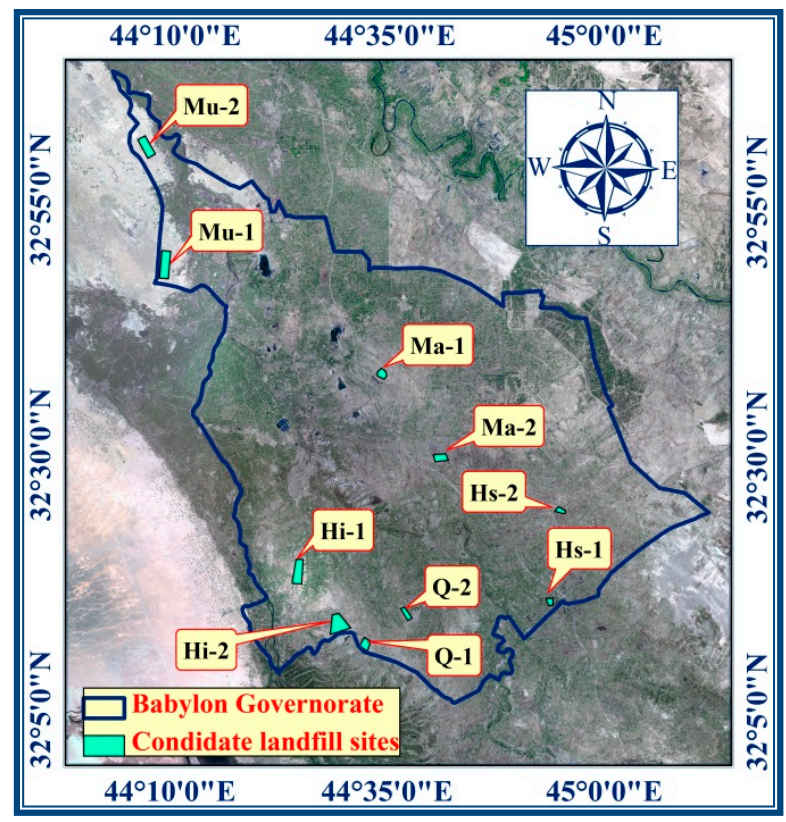

Figure 2. The candidate selected sites for landfill in the Qadhaas of Babylon Governorate.

All of the areas in Babylon Governorate are covered by alluvial deposits at depths of more than $50 \mathrm{~m}$, where no rocks are exposed in this area. The study area is located outside the range of faults and cracks [47]. The soil investigations for the new candidate sites were conducted in 2016 by the Iraqi Ministry of Housing \& Construction, the National Center for Construction Laboratories, and Research Babylon in Iraq in order to check the soil characteristics and water table of the selected sites for landfill in the field. The results showed close similarity with field tests [48], according to Chabuk et al. [49]. Table 1 shows the soil properties and ground water depth at each site, according to Figure 2. 
Table 1. Summary of the soil compositions of sites and their material characteristics [49]. USDA: United States Department of Agriculture; USCS: the Unified Soil Classification System.

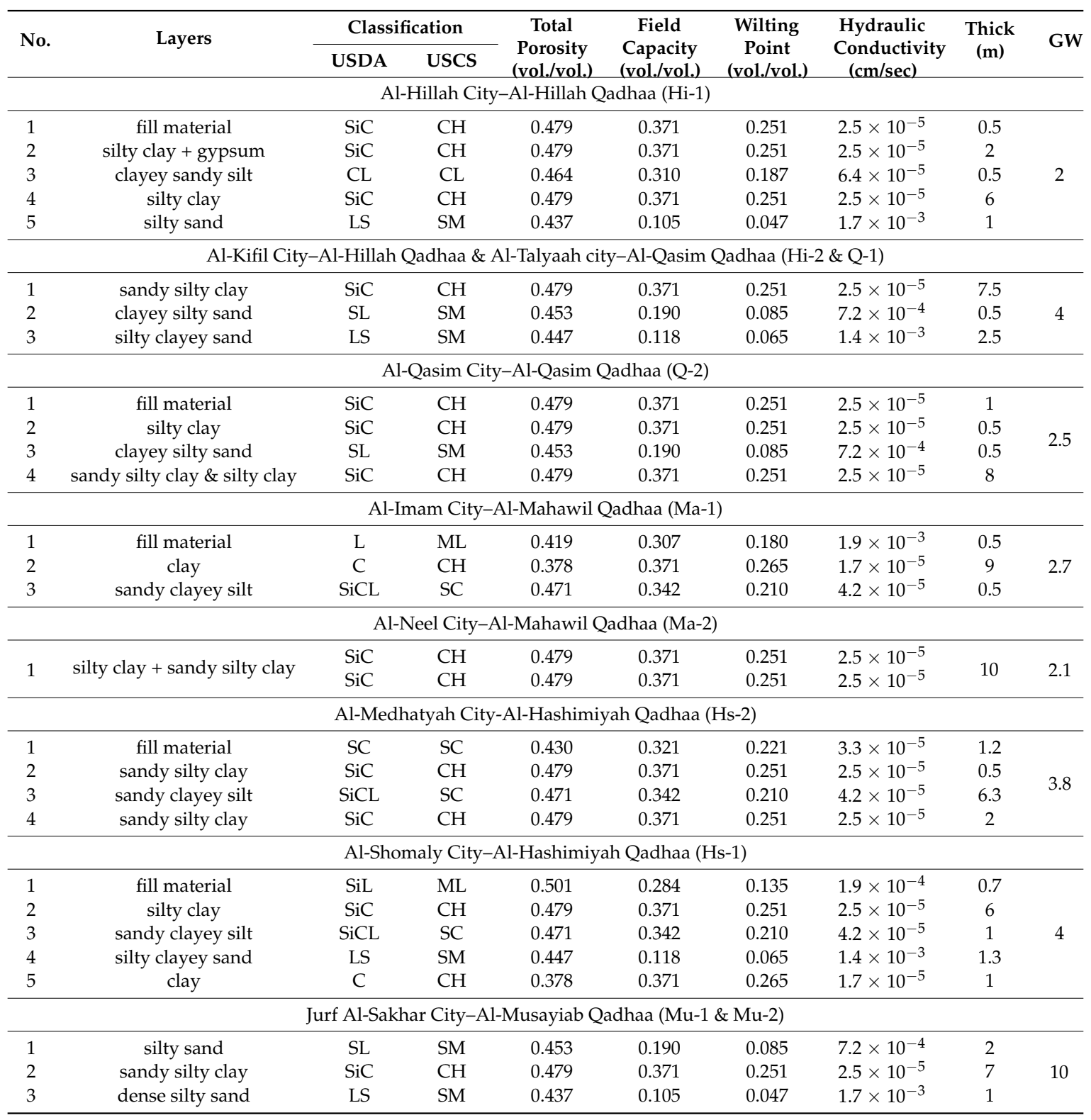

\section{Methodology}

\subsection{The HELP 3.95D Model}

The Hydrologic Evaluation of Landfill Performance (HELP 3.95D) model is the most common practical model in the world for computing the water balance of cover and bottom liners for landfills and contaminated sites. The HELP model has a history extending back 30 years, with many versions, from version 1 to version 3.95D. The HELP model is known as a "quasi-two dimensional" layer model, which does not calculate a two-dimensional flow; however, it does calculate the vertical dimension flow and lateral dimension flows. In the HELP model, the default daily weather data for a range from 1 to 100 calendar years should be entered to compute the soil design data. This model can be used to design the bottom cover systems and the liner systems for open or closed landfills [28].

The HELP model has a high ability to calculate amounts of evapotranspiration, potential and actual runoff, the collected lateral drainage of leachate, and the leakage or percolation of leachate 
through the base liner of landfill designs [30]. The main aim of the model is to include the hydrologic characteristic of the site to assist the landfill designers. In addition, the model can be applied to completely closed, partially closed, and open sites alike [28,30].

\subsection{The Required Input Data for the Model}

\subsubsection{Daily Weather Data of Study Area}

In the current study, the daily data of precipitation (daily depth), air temperature (daily mean), and the solar radiation (daily sum) from 12 consecutive full calendar years (2005-2016) for Babylon Governorate [42] were entered into the HELP model. The average annual data for these parameters in Babylon Governorate can be seen in Table 2. The HELP model has the ability to deal with data from specific periods in the selected study area.

Table 2. Average annual data of weather parameters for the years 2005-2016 in Babylon Governorate [42].

\begin{tabular}{ccccccccccccc}
\hline Parameters & $\mathbf{2 0 0 5}$ & $\mathbf{2 0 0 6}$ & $\mathbf{2 0 0 7}$ & $\mathbf{2 0 0 8}$ & $\mathbf{2 0 0 9}$ & $\mathbf{2 0 1 0}$ & $\mathbf{2 0 1 1}$ & $\mathbf{2 0 1 2}$ & $\mathbf{2 0 1 3}$ & $\mathbf{2 0 1 4}$ & $\mathbf{2 0 1 5}$ & $\mathbf{2 0 1 6}$ \\
\hline $\begin{array}{c}\text { Precipitation mm } \\
\text { (daily depth) }\end{array}$ & 73.2 & 170.3 & 41 & 51.8 & 52.4 & 87.3 & 41.7 & 128.8 & 182.9 & 125 & 133.4 & 135.4 \\
$\begin{array}{c}\text { Temperature }{ }^{\circ} \mathrm{C} \\
\quad \text { (daily mean) }\end{array}$ & 23.1 & 23.5 & 23.5 & 23.6 & 23.9 & 23.6 & 23.2 & 24.1 & 23.3 & 24.2 & 24.6 & 24.5 \\
$\begin{array}{c}\text { Solar radiation MJ } / \mathrm{m}^{2} \\
\quad \text { (daily sum) }\end{array}$ & 5630 & 5638 & 5636 & 5673 & 5643 & 5628 & 5628 & 5702 & 5647 & 5639 & 5736 & 5729 \\
\hline
\end{tabular}

\subsubsection{Estimating Daily Runoff and Runoff Curve Number}

The relationship between runoff and rainfall is calculated in the HELP model based on the SCS (Soil Conservation Service ) curve number method, according to the following Equation (1) [18,30]:

$$
Q=\frac{\left(P-0.2 S^{2}\right)}{(P+0.8 S)}
$$

where $Q$ is the actual runoff or excess of rainfall $(\mathrm{mm}), P$ is the actual rainfall depth $(\mathrm{mm})$, and $S$ is the maximum potential retention after runoff starts (retention parameter) $(\mathrm{mm})$. It is calculated by the following formula.

In the HELP model, the antecedent moisture condition (AMC-II) runoff curve number for slope surface $\left(\mathrm{CN}_{\mathrm{II}}\right)$ was estimated $[18,30]$ as follows:

$$
C N_{\mathrm{II}}=100-(100-\mathrm{CNIIo})\left(\frac{L^{* 2}}{S^{*}}\right)^{C N I I o^{-0.81}}
$$

where $C N_{\text {II }}$ is the curve number that adjusts for surface slope conditions, $C N_{I I o}$ is the AMC-II curve number unadjusted for slope, which is calculated based on constants for vegetation and soil type, $L^{*}$ is the standardized length of the slope $(L / 500 \mathrm{ft})$ (dimensionless), and $S^{*}$ is the standardized slope (S/0.04) (dimensionless).

In the HELP model, the runoff curve number value was 93.80, where it was estimated based on the soil database using soil texture number 27 (moderate compacted sandy clay), the kind of vegetation (poor stands of grass), a surface slope of $10 \%$, and the length of the slope at $75 \mathrm{~m}$.

\subsubsection{Potential and Actual Evapotranspiration Date}

Evapotranspiration (ET) is the process of transferring water by evaporation from the soil profile and other surfaces, as well as from plants, by transpiration. Evaporation alone occurs from open water surfaces or from ground surfaces and vegetation, while the process of transpiration is the extraction of 
water from the soil by the roots of plants, which then evaporates into the atmosphere from the plant's leaves $[18,30]$.

Potential evapotranspiration (PE) is the maximum amount of evaporation that occurs over a day as the amount of unbounded water is extracted by the atmosphere from land $[18,30]$.

In the HELP model, the potential evapotranspiration is calculated based on a modified Penman equation (1963) using the following Equations (3) and (4) [18,30]:

$$
\begin{gathered}
P E T_{\mathrm{i}}=\frac{L E_{s i}}{L_{V}} \\
\text { and } L_{V}=59.7-0.0564 T_{C i}
\end{gathered}
$$

where $P T i$ is the potential evapotranspiration on day $\mathrm{i}(\mathrm{mm}) ; L E_{s i}$ is the available energy for potential evapotranspiration on day $i\left(\mathrm{MJ} / \mathrm{mm}^{2}\right) ; L_{V}$ is the vaporization latent heat $\left(\mathrm{MJ} / \mathrm{mm}^{2} / \mathrm{mm}\right)$; and $T_{C i}$ is the mean air temperature $\left({ }^{\circ} \mathrm{C}\right)$.

Actual evapotranspiration (AE) is the amount of evapotranspiration that occurs when there is a limit to the amount of available water. The actual evapotranspiration (AETi) for segment $j$ on day $i$ is the sum of the actual soil water evaporation (ESWi) and the actual plant transpiration (EPi) from segment $j[18,30]$.

$$
\operatorname{AETi}(j)=\operatorname{ESWi}(j)+\operatorname{EPi}(j)
$$

The actual total evapotranspiration (TEi) on day $i$ is resulted from the summation of the subsurface evapotranspiration (ESSi) and evaporation of surface (ESi) [18,30].

$$
T E i=E S i+E S S i
$$

In the HELP model, calculating the potential and actual evapotranspiration is done by going to the "Data input" item on the main menu, and selecting the evapotranspiration option. The window is then completed with the required information about this option, as follows [29]:

In the HELP model, the potential and actual evapotranspiration in Babylon Governorate at a geographic latitude of (32.5) were computed based on the following required information:

* In the study area, the depth of the evaporative zone is $50 \mathrm{~cm}$, depending on the field tests.

* The maximum index value of the leaf area (area/area) for the study area is (1), because the kind of vegetation in the selected sites was poor strands of grass [29].

* The date for the start day of the growing season over the 12-year period in Babylon Governorate is 10 January, while the date for the last day of the growing season is 15 December, 350 days later [42].

* The required annual average wind speed in the Babylon Governorate at $2 \mathrm{~m}$ above the ground that was input into the HELP model was $7.2 \mathrm{~km} / \mathrm{h}[29,41]$.

* Normal average quarterly relative humidity. Each quarter consists of the average value of three months, where the four quarters of a year are (January to March), (April to June), (July to September) and (October to December) [29]. Therefore, the average values of relative humidity in Babylon Governorate are: for the first quarter $(64.2 \%)$, the second quarter $(39.03 \%)$, third quarter $(34.24 \%)$, and fourth quarter $(60.95 \%)$ [41].

\subsubsection{Soil and Design Data}

The required information for the soil design data in the HELP model [29] are summarized in the following subsections:

1. The characteristics and required data for designing soil layers in the HELP model.

There are 44 types of soil material characteristics in the HELP model according to [29], depending on the two standards systems from the United States Department of Agriculture (USDA) and the 
Unified Soil Classification System (USCS). The types of soil texture from 1 to 15 in addition to 21 are classified as low-density soils. The types of soil texture from 22 to 29 are considered moderate-density soils, while the types of soil texture 16 and 17 are represented high-density soils. The types of soil texture from 35 to 42 are defined as geomembrane and geotextile. The default types of waste in this model are from 18 to 19 and from 30 to 33 .

The required data for the suggested soil layers are: thickness of layers (metric: $\mathrm{cm}$ ), the default soil texture according to the USDA system and the USCS system, porosity (vol./vol.), field capacity (vol./vol.), the wilting point (vol./vol.), saturated hydraulic conductivity $(\mathrm{cm} / \mathrm{sec})$, and the required design data for the lateral drainage layer, including the length of drainage $(\mathrm{m})$ and the slope of drain (\%) [29].

The properties of soil sites for the selected new landfills that were conducted by [48] did not comply with the international standard requirements for landfill design. In this study, the type and properties of the suggested soil layers were used as standard materials for the new landfill sites. The type and properties of the suggested soil layers correspond with international requirements for landfill design based on the two standards systems (USDA) and (USCS), where these systems are adopted in Iraq. The properties of standard soil layers were selected to be similar to the soil properties that are available, particularly in Babylon Governorate and generally in Iraq [48]. Some of the remaining soil materials (excavated soil) may be used as a daily cover, an intermediate cover, or for other uses, according to the specialists in this field.

2. Type of layers for landfill in the HELP model

The required layers for constructing the model of a landfill are as follows [18]:

(a) Vertical percolation layer (VPL)

Vertical percolation layer includes a waste layer and layers of soil designed to support vegetation on the surface. The water drains downward through the vertical unsaturated layers by gravity. In the HELP model, the unsaturated hydraulic conductivity through waste and soil layers was calculated according to (Equation (7)) by Campbell (1974) based on Darcy's law, as follows [30]:

$$
K_{u}=K_{s}\left[\frac{\theta-\theta_{r}}{\varnothing-\theta_{r}}\right]^{3+(2 / \lambda)}
$$

where $K_{u}$ is unsaturated hydraulic conductivity $(\mathrm{cm} / \mathrm{sec}), K_{\delta}$ is saturated hydraulic conductivity $(\mathrm{cm} / \mathrm{sec}), \theta$ is actual volumetric water content ( $\mathrm{vol} / \mathrm{vol}), \theta_{r}$ is residual volumetric water content (vol./vol.), $\varnothing$ is total porosity (vol./vol.), and $\lambda$ is the index of pore-size distribution (dimensionless).

(b) Lateral drainage layer (LDL)

This layer is placed directly above the layer of the barrier soil liner to collect water infiltration and rapidly remove it.

In the HELP model, for lateral drainage flow of small and large rates drainage, the average saturation depth on top of the liners, and the rate of drainage were calculated based on Equation (8) and Equation (9), respectively [30], as follows:

$$
\begin{gathered}
\widetilde{\mathrm{y}}^{*}=\frac{q *_{D}}{2(\sin \alpha)(\cos \alpha)},\left(q *_{D}<0.4 \sin ^{2} \alpha, \text { for small drainage rate }\right) \\
\operatorname{or}\left(q *_{D}>0.4 \sin 2 \alpha, \text { for large drainage rate }\right) \\
*_{D}=2(\sin \alpha)(\cos \alpha) \widetilde{\mathrm{y}}^{*},\left(\widetilde{\mathrm{y}}^{*}<0.2 \text { tan } \alpha, \text { for small drainage rate }\right) \\
\text { or }\left(\widetilde{\mathrm{y}}^{*}>0.2 \tan \alpha, \text { large drainage rate }\right)
\end{gathered}
$$

where $(\widetilde{\mathrm{y}})$ is the average saturation depth on top of the liners (non-dimension), $q^{*} D$ is the rate of lateral drainage of flow for each unit area of landfill $(\mathrm{cm} / \mathrm{sec})$, and $\alpha$ is the liner surface inclination angle. 
(c) Barrier soil liners (BSL)

A layer of the barrier soil liner is used to prevent the vertical drainage of leachate from this layer, since the hydraulic conductivity of this layer is very low. The pressure head is assumed to be constant in the HELP model within layers of vertical infiltration and lateral drainage. The HELP model is assuming that the head of pressure is uniformly dispersed within the soils of low permeability, where this model allows for flow moving only down in barrier soil [30].

The rate of percolation through a soil liner of low permeability is calculated by Equation (10) based on Darcy's law, as follows [18,30]:

$$
Q_{p}(p)_{i}=K S(n+1) \frac{h_{w}(p)+T S(n+1)}{T S(n+1)}
$$

where $Q_{p}(p)_{i}$ is the rate of percolation from the profile of sub-layers (p) during time $i$ (cm/day), Ks is the saturated hydraulic conductivity of the soil liner $(\mathrm{cm} / \mathrm{sec}), h_{w}$ is the average pressure head of the sub-profile $\mathrm{k}$ on the top of the liner $(\mathrm{cm})$, TS is the thickness of the layer $(\mathrm{cm})$, and $n$ is the number of layers in sub-profile $\mathrm{k}$ above the soil liner.

(d) Geomembrane liners (GL)

This is a layer of impervious, artificial flexible membrane that is used together with barrier soil liners to prevent leachate percolation. To calculate the flows of total leakage through the geomembrane in the HELP model, Equation (11) was used, according to Schroeder et al. [30]:

$$
q_{L T}=q_{L 1}+q_{L 2}+q_{L 3}
$$

where $q_{L T}$ is the total leakage, $q_{L 1}$ is the leakage through intact geomembrane sections, $q_{L 2}$ is the leakage through pinhole-size flaws, and $q_{L 3}$ is the leakage through the defect-size geomembrane flaws.

\subsubsection{Suggested Soils Layers' Data}

1. Site layout of the landfill

The landfill site should be divided into many zones, where each zone is used to accommodate the quantity of waste over a one-year period. In this study, the lifespan of the selected landfill is 10 years. Therefore, the area of each selected site will be divided into 10 zones (one zone for each year). Each zone will be subdivided into a number of cells, so that the areas of cells are sufficient to accommodate the quantity of waste during the design lifespan of each zone (12 months).

The quantity of waste $\left(Q_{s}\right)$ produced each year until the year 2030 was calculated based on the following equation [35]:

$$
Q_{s}(\text { For specific year })=\left(\left(P_{0(2013)}(1+r)^{n}\right) \times\left(G R W_{(2013)}(1+R G I)^{n}\right) \times(365 / 1000)\right)
$$

where $Q_{s}$ is the quantity of waste produced each year (tonnes), $P_{0}$ is the present population of the city for each year (starting from the year 2013), $r$ is an annual growth rate of $2.99 \%, n$ is the number of years, GRW is the present generation rate of solid waste ( $\mathrm{kg} /$ capita.day) for the year 2013, and RGI is the rate of increment in waste generation per year equal to 0.01 ( $\mathrm{kg} /$ capita.day).

The required area for each Qadhaa in Babylon Governorate was calculated as follows:

- The volume of waste was calculated by dividing the quantity of waste $\left(Q_{s}\right)$ produced each year until the year 2030 by the waste density $\left(450 \mathrm{~kg} \mathrm{~m}^{-3}\right)$ at the waste disposal sites in Babylon Governorate and its Qadhaas [35].

- The required areas of the candidate sites that emerged as a result of the previous studies was calculated by dividing by $2 \mathrm{~m}$, which represents the height of municipal solid waste that will be 
placed on the surface since the groundwater depth in the study areas is shallow, and in order to reduce the cost of constructing a perimeter berm around the site.

- GIS and multi-criteria decision making methods were used to determine the best sites for landfill, and the location and dimension for these sites for design purposes was determined.

A summary of the required areas and the areas of the candidate sites for landfill and their locations, as well as the required area and the cross-section for the design of the landfills, are shown in Table 3.

The area of each zone $(\mathrm{km})$ was derived by dividing the quantity of waste $(\mathrm{kg})$ for a specific year by the sum of the products of multiplying the density of solid waste $\left(450 \mathrm{~kg} / \mathrm{m}^{3}\right)$ [39] by the height of the waste $(2 \mathrm{~m})$.

The area of each zone will be divided into a number of cells. The area of each specific cell is enough to receive the quantity of waste for each month during one year. The quantity of waste $\left(Q_{s}\right)$ for each year from 2020 until 2030, and the required area for each zone in the each candidate site, can be seen in Table 4.

For each final cell, when using a waste layer height equal to $400 \mathrm{~cm}$, the required area for landfill will be reduced by $50 \%$. Consequently, the area of each zone will reduce to half of the area needed. In this case, the life span of each selected site will be extended from 10 to 18 years (or from 2030 to 2038), given that the typical height of waste is between $2-4 \mathrm{~m}$ according to [50].

Table 3. The required area, the areas, and locations of candidate sites for landfill in the Qadhaas of Babylon Governorate, as well the available area for landfill designs [51].

\begin{tabular}{|c|c|c|c|c|c|}
\hline \multirow{2}{*}{ Qadhaa } & \multirow{2}{*}{$\begin{array}{l}\text { Requited } \\
\text { Area }\left(\mathbf{k m}^{2}\right)\end{array}$} & \multicolumn{2}{|c|}{ Area of Candidate Sites } & \multirow{2}{*}{ Location } & \multirow{2}{*}{$\begin{array}{l}\text { Available Area } \\
\text { for Design }\left(\mathrm{km}^{2}\right)\end{array}$} \\
\hline & & Site Symbol & Area $\left(\mathrm{km}^{2}\right)$ & & \\
\hline Al-Hillah & 4.778 & $\begin{array}{l}\mathrm{Hi}-1 \\
\mathrm{Hi}-2\end{array}$ & $\begin{array}{l}4.45 \times 1.52 \\
(6.768) \\
3.24 \times 2.53 \\
(8.204)\end{array}$ & $\begin{array}{c}\text { Latitude } 32^{\circ} 18^{\prime} 45^{\prime \prime} \mathrm{N} \\
\text { Longitude } 44^{\circ} 24^{\prime} 40^{\prime \prime} \mathrm{E} \\
\text { Latitude } 32^{\circ} 13^{\prime} 43^{\prime \prime} \mathrm{N} \\
\text { Longitude } 44^{\circ} 29^{\prime} 15^{\prime \prime} \mathrm{E}\end{array}$ & $\begin{array}{l}3.4 \times 1.5 \\
(5.1) \\
2.5 \times 2 \\
(5)\end{array}$ \\
\hline Al-Qasim & 0.772 & $\begin{array}{l}\text { Q-1 } \\
\text { Q-2 }\end{array}$ & $\begin{array}{l}1.73 \times 1.6 \\
(2.766) \\
2.5 \times 0.822 \\
(2.055)\end{array}$ & $\begin{array}{c}\text { Latitude } 32^{\circ} 11^{\prime} 43^{\prime \prime} \mathrm{N} \\
\text { Longitude } 44^{\circ} 32^{\prime} 26^{\prime \prime} \mathrm{E} \\
\text { Latitude } 32^{\circ} 14^{\prime} 38^{\prime \prime} \mathrm{N} \\
\text { Longitude } 44^{\circ} 37^{\prime} 10^{\prime \prime} \mathrm{E}\end{array}$ & $\begin{array}{l}1.2 \times 1 \\
(1.2) \\
1.5 \times 0.8 \\
(1.2)\end{array}$ \\
\hline Al-Hashimiyah & h 1.013 & $\begin{array}{l}\text { Hs-2 } \\
\text { Hs-1 }\end{array}$ & $\begin{array}{l}1.69 \times 0.813 \\
(1.374) \\
1.24 \times 1.038 \\
(1.288)\end{array}$ & $\begin{array}{c}\text { Latitude } 32^{\circ} 24^{\prime} 51^{\prime \prime} \mathrm{N} \\
\text { Longitude } 44^{\circ} 54^{\prime} 41^{\prime \prime} \mathrm{E} \\
\text { Latitude } 32^{\circ} 15^{\prime} 54^{\prime \prime} \mathrm{N} \\
\text { Longitude } 44^{\circ} 53^{\prime} 38^{\prime \prime} \mathrm{E}\end{array}$ & $\begin{array}{l}1.3 \times 1 \\
(1.3) \\
1.2 \times 1.1 \\
(1.32)\end{array}$ \\
\hline Al-Mahawil & 0.975 & $\begin{array}{l}\text { Ma-2 } \\
\text { Ma-1 }\end{array}$ & $\begin{array}{l}1.543 \times 1.438 \\
(2.218) \\
2.23 \times 1.323 \\
(2.950)\end{array}$ & $\begin{array}{l}\text { Latitude } 32^{\circ} 38^{\prime} 12^{\prime \prime} \mathrm{N} \\
\text { Longitude } 44^{\circ} 34^{\prime} 9^{\prime \prime} \mathrm{E} \\
\text { Latitude } 32^{\circ} 29^{\prime} 59^{\prime \prime} \mathrm{N} \\
\text { Longitude } 44^{\circ} 41^{\prime} 2^{\prime \prime} \mathrm{E}\end{array}$ & $\begin{array}{l}1.1 \times 1.1 \\
(1.21) \\
1.1 \times 1.1 \\
(1.2)\end{array}$ \\
\hline Al-Musayiab & 2.080 & $\begin{array}{l}\mathrm{Mu}-1 \\
\mathrm{Mu}-2\end{array}$ & $\begin{array}{l}4.9 \times 1.626 \\
(7.965) \\
3.76 \times 1.583 \\
(5.952)\end{array}$ & $\begin{array}{l}\text { Latitude } 32^{\circ} 48^{\prime} 39^{\prime \prime} \mathrm{N} \\
\text { Longitude } 44^{\circ} 8^{\prime} 59^{\prime \prime} \mathrm{E} \\
\text { Latitude } 33^{\circ} 0^{\prime} 14^{\prime \prime} \mathrm{N} \\
\text { Longitude } 44^{\circ} 6^{\prime} 46^{\prime \prime} \mathrm{E}\end{array}$ & $\begin{array}{l}1.5 \times 1.5 \\
(2.25) \\
1.5 \times 1.5 \\
(2.25)\end{array}$ \\
\hline
\end{tabular}


Table 4. The quantity of waste, and the area of each selected landfill zone in the Qadhaas of Babylon Governorate to accommodate waste between 2020-2030.

\begin{tabular}{|c|c|c|c|c|c|c|c|c|c|c|}
\hline \multirow{2}{*}{ Year } & \multicolumn{2}{|c|}{ Hillah } & \multicolumn{2}{|c|}{ Qasim } & \multicolumn{2}{|c|}{ Mahawil } & \multicolumn{2}{|c|}{ Hashimiyah } & \multicolumn{2}{|c|}{ Musayiab } \\
\hline & $\begin{array}{c}\text { Waste } \\
\left(T^{1}\right)\end{array}$ & $\begin{array}{l}\text { Z.A. } \\
\left(\text { ha }^{3}\right)\end{array}$ & $\begin{array}{c}\text { Waste } \\
\text { (T) }\end{array}$ & $\begin{array}{l}\text { Z.A. } \\
\text { (ha) }\end{array}$ & $\begin{array}{l}\text { Waste } \\
(\mathrm{T})\end{array}$ & $\begin{array}{l}\text { Z.A. } \\
\text { (ha) }\end{array}$ & $\begin{array}{l}\text { Waste } \\
\text { (T) }\end{array}$ & $\begin{array}{l}\text { Z.A. } \\
\text { (ha) }\end{array}$ & $\begin{array}{l}\text { Waste } \\
(\mathrm{T})\end{array}$ & $\begin{array}{l}\text { Z.A. } \\
\text { (ha) }\end{array}$ \\
\hline 2020 & 318,576 & 35.4 & 51,497 & 5.7 & 64,993 & 7.2 & 67,532 & 7.5 & 138,760 & 15.4 \\
\hline 2021 & 331,383 & 36.8 & 53,567 & 6.0 & 67,605 & 7.5 & 70,246 & 7.8 & 144,338 & 16.0 \\
\hline 2022 & 344,704 & 38.3 & 55,720 & 6.2 & 70,323 & 7.8 & 73,070 & 8.1 & 150,140 & 16.7 \\
\hline 2023 & 358,561 & 39.8 & 57,960 & 6.4 & 73,150 & 8.1 & 76,008 & 8.4 & 156,176 & 17.4 \\
\hline 2024 & 372,974 & 41.4 & 60,290 & 6.7 & 76,090 & 8.5 & 79,063 & 8.8 & 162,454 & 18.1 \\
\hline 2025 & 387,968 & 43.1 & 62,714 & 7.0 & 79,149 & 8.8 & 82,241 & 9.1 & 168,984 & 18.8 \\
\hline 2026 & 403,563 & 44.9 & 65,235 & 7.2 & 82,331 & 9.1 & 85,547 & 9.5 & 175,777 & 19.5 \\
\hline 2027 & 419,786 & 46.6 & 67,857 & 7.5 & 85,641 & 9.5 & 88,986 & 9.9 & 182,843 & 20.3 \\
\hline 2028 & 436,661 & 48.5 & 70,585 & 7.8 & 89,083 & 9.9 & 92,563 & 10.3 & 190,193 & 21.1 \\
\hline 2029 & 454,215 & 50.5 & 73,422 & 8.2 & 92,664 & 10.3 & 96,284 & 10.7 & 197,839 & 22.0 \\
\hline 2030 & 472,474 & 52.5 & 76,374 & 8.5 & 96,389 & 10.7 & 100,155 & 11.2 & 205,792 & 22.9 \\
\hline
\end{tabular}

\section{Base design level of landfill}

The level of landfill base should be placed at a minimum of $1.5 \mathrm{~m}$ above the groundwater table [52], or $2 \mathrm{~m}$ [53]. The distance from the base of the landfill to the groundwater table was higher than $2 \mathrm{~m}$ at all of the selected sites for landfill in Babylon Governorate.

\section{Base liner layer}

The purpose of using the base liner in a landfill is to prevent, decrease, degrade, and delay the soil contamination and groundwater by leakage of leachate from the landfill sites. The base liner is used to filter the leachate within this layer and prevent the lateral flow of leachate $[25,54,55]$. The base liner of a landfill includes a geosynthetic clay liner, and/or a secondary compacted clay liner, which includes a primary geomembrane liner that is defined as a composite liner layer $[29,56]$. The slope of the surface liner should be at least $2 \%$ [13].

In this design, the layer (8) consists of a highly compacted clay (barrier soil) with a thickness of $60 \mathrm{~cm}[57,58]$, and the effective saturate of hydraulic conductivity $(\mathrm{cm} / \mathrm{sec})$ was $1.0 \times 10^{-7}[14,52,59]$.

\section{Geomembrane and geotextile layers}

The geomembrane liner layer is used to reduce the quantity of pollutants affecting the groundwater [56]. The service life for the primary geomembrane liner (HDPE) should be 100 years, based on anticipated operating temperatures and a thickness of $0.15 \mathrm{~mm}[52,54]$. In the HELP model, the geomembrane types (from 35 to 42 ) should include the following parameters: thickness, pinhole density, installation defect density, placement quality (available six values), drainage slope, and drainage length [29].

In the HELP model, the specifications for the liner layer (7) included a flexible membrane liner of high-density polyethylene (HDPE) with a thickness of $0.15 \mathrm{~mm}$, a hydraulic conductivity $(\mathrm{cm} / \mathrm{sec})$ of $2.0 \times 10^{-13}$ a drainage slope of $3 \%$, and a drainage length of $30 \mathrm{~m}$.

The non-woven geotextile layer type 4 (butyl rubber) was placed on the drainage blanket under the protective layer with a drain length of $30 \mathrm{~m}$ and a slope of $5 \%$. The hydraulic conductivity of this layer was $1.0 \times 10^{-12} \mathrm{~cm} / \mathrm{s}$. The thickness of this layer was $150 \mathrm{~mm}$. This layer was used to prevent clogging within the gravel layer and the transference of small grained particles into this layer [13]. 


\section{Lateral drainage layer}

The layer of lateral drainage is installed within the leachate collection system to prevent leachate from the landfill, as well to control the leachate rising above the base liner of the landfill [25,52]. The efficient drainage of leachate will reduce the pollution water that comes from the saturated waste zones at the bottom of a landfill, as well as increase the mechanical stability of the landfill, thus reducing the dangers of mechanical failure of the landfill during events of intense rainfall [13]. For protecting the leachate collector pipes and reducing the possibility of fine particles of waste and air entering into the drainage blanket layer, a geotextile layer can be placed over the drainage blanket layer to perform the same function of protecting the drainage blanket layer from becoming clogged [13,52].

The minimum design requirements for a leachate collection and removal system are as follows:

$>$ The material of the drainage blanket layer includes gravel material $[25,55,60]$.

$>$ The thickness of the leachate collection system (including the drainage blanket layer) should be $30 \mathrm{~cm}[55,60,61]$.

$>$ The maximum lateral spacing of the main leachate collection pipes are $15 \mathrm{~m}$ [13], equal or less than $25 \mathrm{~m}$ [60], or $30 \mathrm{~m}$ [62].

$>$ The space between each lateral pipe is $2 \mathrm{~m}$ [54].

$>$ The maximum length of the drainage is $50 \mathrm{~m}$ [52].

$>$ The minimum diameter of the collection pipes should be $150 \mathrm{~mm}[52,55,60]$ or $200 \mathrm{~mm}$ [25].

$>$ The minimum slope of the main leachate collection pipes that should be laid toward the pit (sump) should be $2 \%[13,14,25,52]$. This slope decreases the risk of the leachate collection pipes clogging, because they will be self-cleaning [25].

$>$ The minimum lateral slope toward the direction of the main leachate collection pipes (transverse direction) should be at least $1 \%$ [25].

$>$ The vertical leachate collection pipes are installed in the landfill site, and the lower end of the vertical pipes are joined to the bottom (horizontal) of the leachate collection pipes so that they can operate as a gas vent [62].

$>$ The inclined leachate collection pipes are distributed along the berm slope and used as a gas vent. These pipes are joined to the bottom of the leachate collection pipes [62].

$>$ A leachate collection pit (sump) allows the leachate to drain by gravitational force, and it is located at the low points in cells, whether the location of the pit is outside or inside the landfill site $[25,62]$.

$>$ An operating pump should be used to remove and lift leachate from the pits to the required head [25].

> The collected leachate should be removed and sent to a treatment facility [13].

In the HELP model, using two scenarios, the slope and the length of drainage net layer (6) in the leachate collection system was $3 \%$ and $30 \mathrm{~m}$, respectively. The thickness of drainage blanket layer (5) is $30 \mathrm{~cm}$, whilst the drain net layer (6) was $0.5 \mathrm{~cm}$. The hydraulic conductivity of the drainage blanket layer was $3.0 \times 10^{-1} \mathrm{~cm} / \mathrm{s}$, while the hydraulic conductivity of the drainage net was $1.0 \times 10^{+1} \mathrm{~cm} / \mathrm{s}$.

6. Protective layer

The protective layer can be placed over the drainage layer to make sure that the drainage layer operates for a long time; it prevents waste particles from moving into the drainage layer, does not destroy the drainage pipes or the drainage layer, and also protects the geotextile from tears when placing the compacted layers of waste $[13,25]$.

In the current model, the protective layer (3) consisted of loam fine sand with a hydraulic conductivity equal to $1.0 \times 10^{-3} \mathrm{~cm} / \mathrm{s}$ [13]. The thickness of this layer was $30 \mathrm{~cm}$ [54]. 


\section{Compacted waste using the scenarios}

In this study, there were two scenarios for placing the compacted waste on top of the protective layer over the surface, with a typical height of the compacted waste of 2-4 $\mathrm{m} \mathrm{[50].}$

The first scenario involved placing waste with a total height of $2 \mathrm{~m}$, and then covering it with a final cover (Figure 3a). In the second scenario, the height process of placing the compacted solid waste over the surface was $4 \mathrm{~m}$ (Figure $3 \mathrm{~b}$ ).

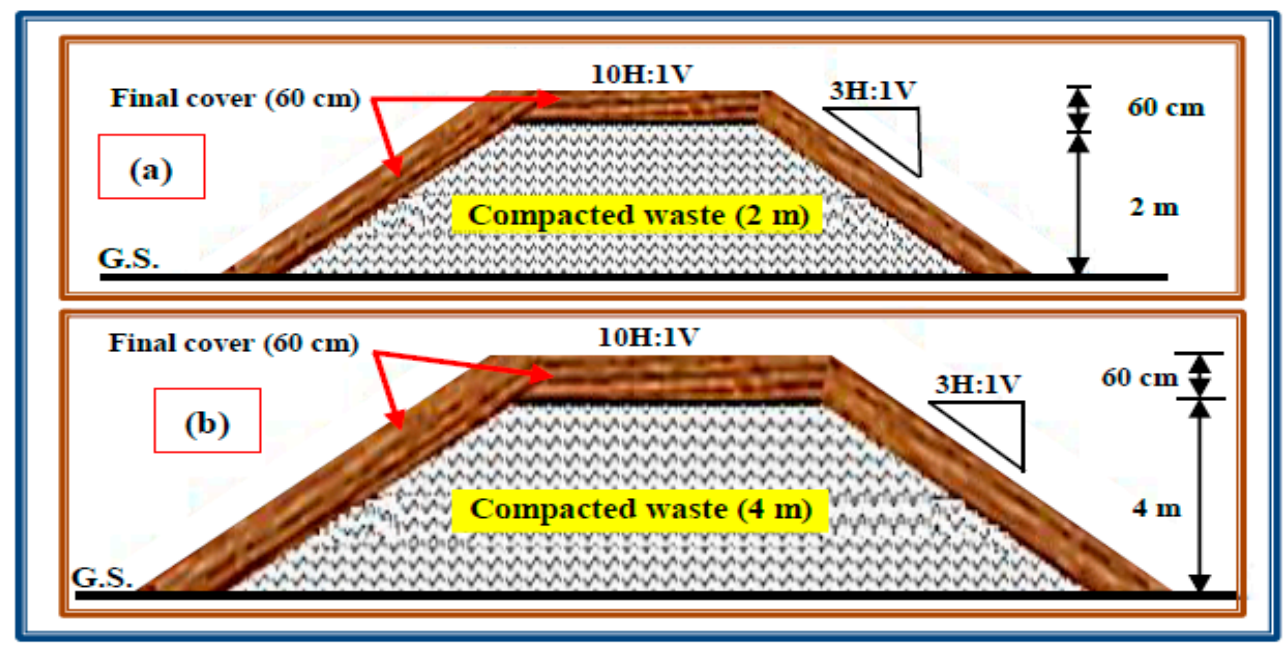

Figure 3. Scenarios for placing compacted waste over the ground surface: (a) the height of the compacted waste layer is $2 \mathrm{~m}$; (b) the height of the compacted waste layer is $4 \mathrm{~m}$ (without scale).

In addition, a further consideration should be the use of a daily cover of $15 \mathrm{~cm}$, or an intermediate cover of $30 \mathrm{~cm}$ (as a temporary cover) when the active face of a single cell of waste does not reach the final capacity of covering the waste layer during, or over more than, a 30-day period, or during the fall seasons $[13,52,57,61]$.

In this study, the value of the saturated hydraulic conductivity of the municipal solid waste was used as a $1.0 \times 10^{-5} \mathrm{~cm} / \mathrm{sect}$ instead of the default value within the HELP model of $1.0 \times 10^{-3}$ This is due to the recent research studies in this field $[63,64]$, which argued that the waste is compacted as a result modern practices in situ $[65,66]$. The default hydraulic conductivity has led to high generation rates of leachate value, where this value of leachate does not represent the real value in the modern landfill [67].

\section{Suggested design for final cover}

The main aims of placing the final cover on a landfill are to reduce odors and methane gas being released into the atmosphere, to avoid humans and wildlife from exposure to municipal solid waste, and to decrease the infiltration of precipitation into the waste and minimize erosion [13].

The steps of placing the final cover during the lifespan of the landfill include the following:

The thickness of the final compacted cover layer is $60 \mathrm{~cm}$ (perpendicular to the slope) (Figure 4a). The thickness of the final compacted cover layer should be $60 \mathrm{~cm}$, as a fixed thickness over a specific period. This layer is low and sensitive to landfill surface settlements [13].

In Babylon Governorate, the waste contains a high percentage of organic material (more than 55\%) [39]. The organic matter will decompose with time, and this will cause the surface layer to be irregular (not horizontal) (Figure 4b). In this case, soil should be added at certain periods of time to keep the surface level. 


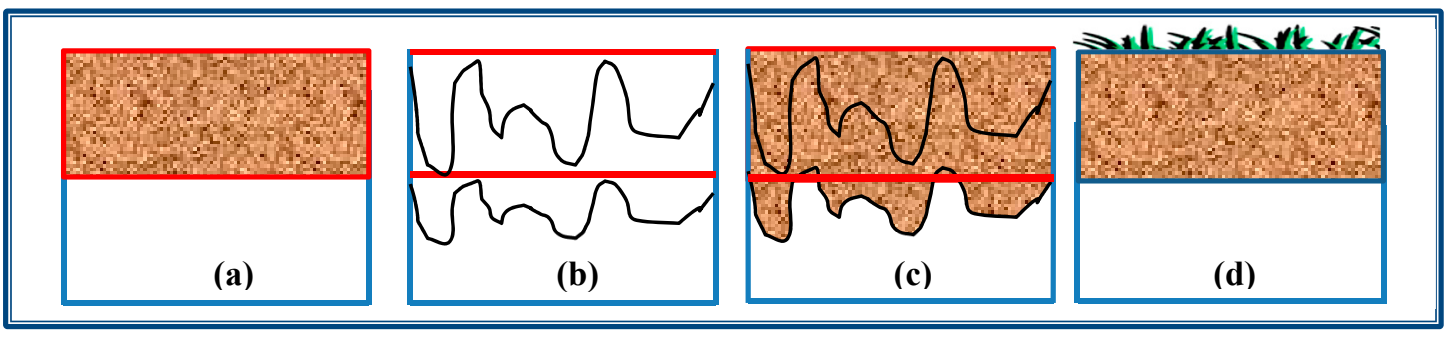

Figure 4. The process of placing the final cover for the suggested landfill: (a) placing the layer of moderately compacted sandy clay with a thickness of $60 \mathrm{~cm}$; (b) the landfill surface settlements due to decomposition of organic materials; (c) adding the material required to maintain a thickness of $60 \mathrm{~cm}$; (d) adding the top soil layer to a thickness of $15 \mathrm{~cm}$.

The same soil materials of the final compacted cover layer will be added when the displacement of the final cover layer stops at the end of the landfill's lifespan. Therefore, the final thickness of the final cover will be $60 \mathrm{~cm}$ (Figure 4c). This layer should be monitored during particular years to avoid settlement when the waste materials have degraded.

The minimum requirement for the top soil layer should be at least $150 \mathrm{~mm}$, which is the necessary depth for the growth of a vegetative layer and to reduce erosion $[13,52,60]$ (Figure $4 \mathrm{~d}$ ). The roots of the vegetation should not extend too deeply, because this would cause damage to the final cover and thus enable the transfer of pollution to the surrounding environment to occur [61].

The systems of gas management and gas vents of $(150 \mathrm{~mm})$ need to be installed at the same time as the placement of the final cover in order to allow any gases that might form in the layers of the covered landfill to be released, where the gas will be transferred to the burning facilities through a vacuum system $[14,58,61]$.

According to the Iraqi Ministry of Housing \& Construction (2016) [48], the bearing capacity for the soils of the selected sites is $50 \mathrm{KN} / \mathrm{m}^{2}$. Consequently, the cumulative loads that result from using $4 \mathrm{~m}$ of height waste, the final soil cover $(60 \mathrm{~cm})$, and the daily covers of soil $(15 \mathrm{~cm})$ are acceptable.

In this study, the composition of the cover layer was moderate compacted sandy clay, and its hydraulic conductivity was $7.8 \times 10^{-7} \mathrm{~cm} / \mathrm{sec}$. [52] stated that hydraulic conductivity of the cover layer in non-arid regions ought to be $\geq 1.0 \times 10^{-7} \mathrm{~cm} / \mathrm{sec}$.

In the current study, the final sketch diagram shows the suggested landfill design when using a height of compacted solid waste of $2 \mathrm{~m}$ (the first scenario), and using a total height of $4 \mathrm{~m}$ of compacted solid waste (the second scenario) (see Figure 5).

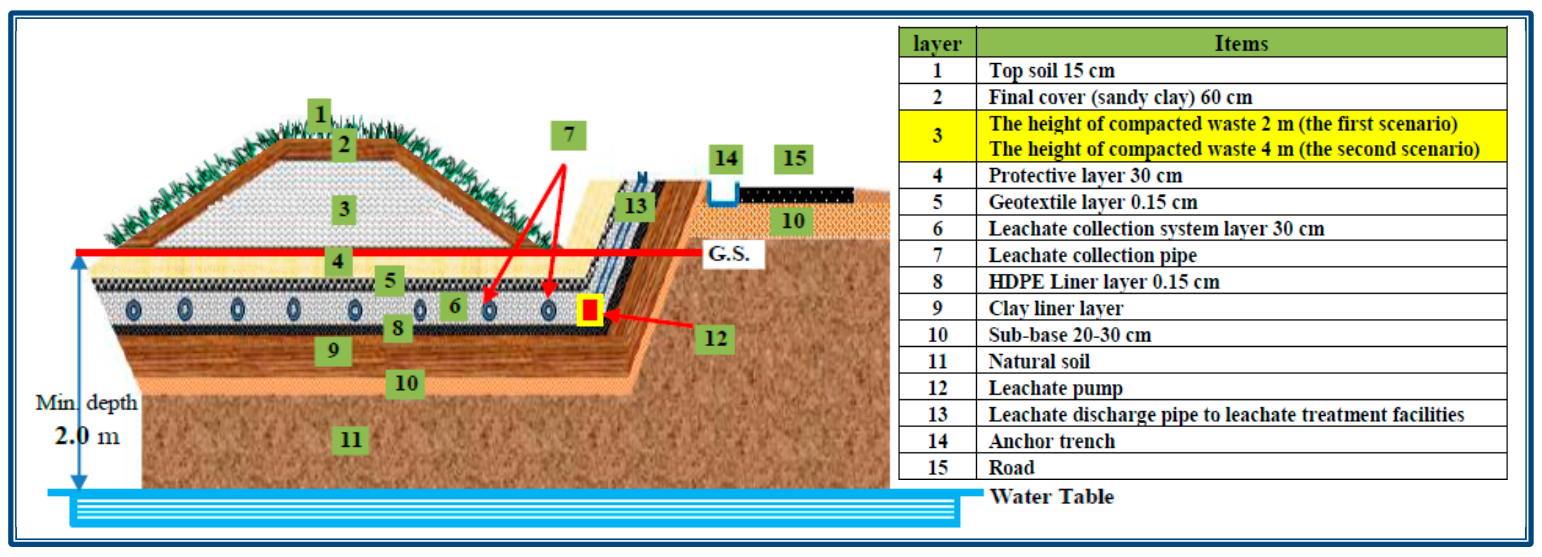

Figure 5. The final sketch diagram of the design for the suggested landfill using two scenarios, with the height of the compacted solid waste at $2 \mathrm{~m}$ and $4 \mathrm{~m}$. 


\subsubsection{Perimeter Berm}

The management of storm water includes run-on and run-off, which usually includes perimeter drainage around the landfilling and leachate treatment areas. The former prevents contact between surface water and waste mass, which reduces leachate production and generation. However, the latter includes diversion ditches, silt fences, down drains, and storm water management ponds. These facilities allow storm water to run-off from the landfill surface and minimize erosion [68].

The perimeter berm is built around the landfill site to act as a natural barrier for the site, and to prevent storm water from entering the site. In addition, the embankment of the perimeter berm is used for the passage of vehicles to the site $[57,58]$. The profile of berm layers has the same composition and thickness as the below ground layers of the landfill [59], where Figure 6 shows the cross-section of berm in this study. The typical height of the berm is either between 2.5 and $3.5 \mathrm{~m}$ [52] or between 3 and $4 \mathrm{~m}$ [54], and at least $0.5 \mathrm{~m}$ high [58]. The surface of the berm extends to the surface of the landfill, but the surface of the berm is then raised with a slope of $3 \mathrm{H}$ to $1 \mathrm{~V}[57,59]$, or 2-2.5H-1V [54]. The anchor trench is constructed along the connecting line of the outside edge of the perimeter berm. The width of the anchor trench was $0.5 \mathrm{~m}$ [57], and the trench was used to collect the water run-off from the surrounding areas of landfills and from the final cover surface of the landfill.

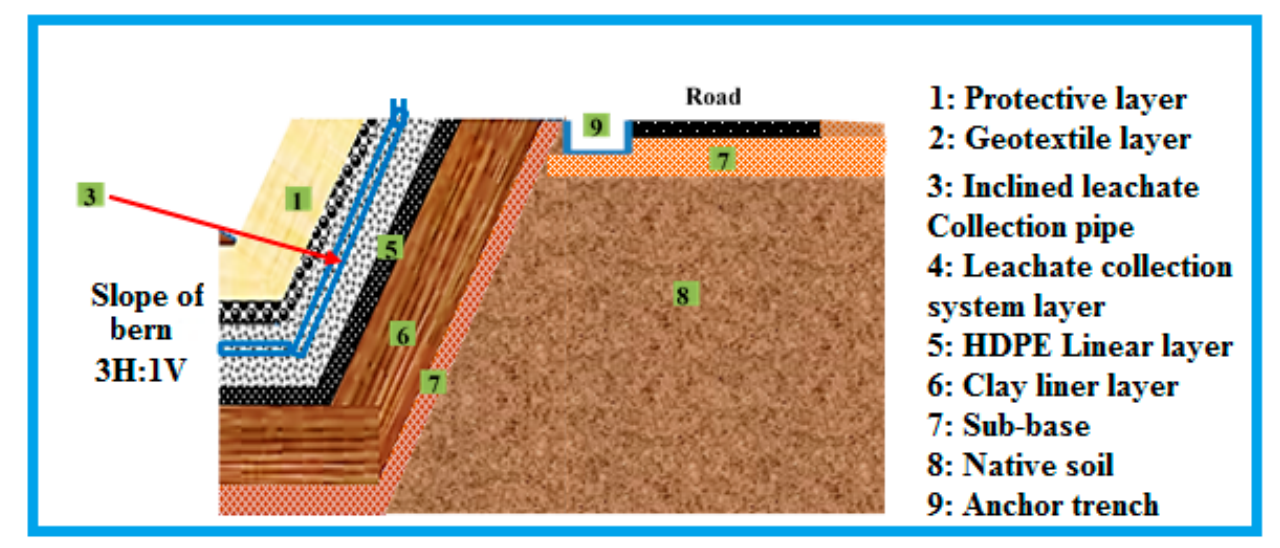

Figure 6. Cross-section of the berm slope and anchor trench in the suggested landfill site (without scale).

\subsubsection{The Suggested Soil Layers that Entered into the HELP 3.95D Model}

In the HELP model, two scenarios were posited for the design of landfills for the selected sites in Babylon Governorate. In the first scenario, eight layers were entered into the HELP model, and this scenario included one lift of waste with a $2 \mathrm{~m}$ height. The second scenario also consisted of eight layers, but the height of compacted waste was equal to $4 \mathrm{~m}$. The characteristics of the data for each layer are layer thickness, porosity, field capacity, wilting point, initial soil water content, and hydraulic conductivity.

Figure 7 shows the profile of the suggested landfill design, which was implemented in the HELP 3.95D model for both the first and second scenario. The summary data for the suggested layers in the two scenarios can be seen in Table 5 . 


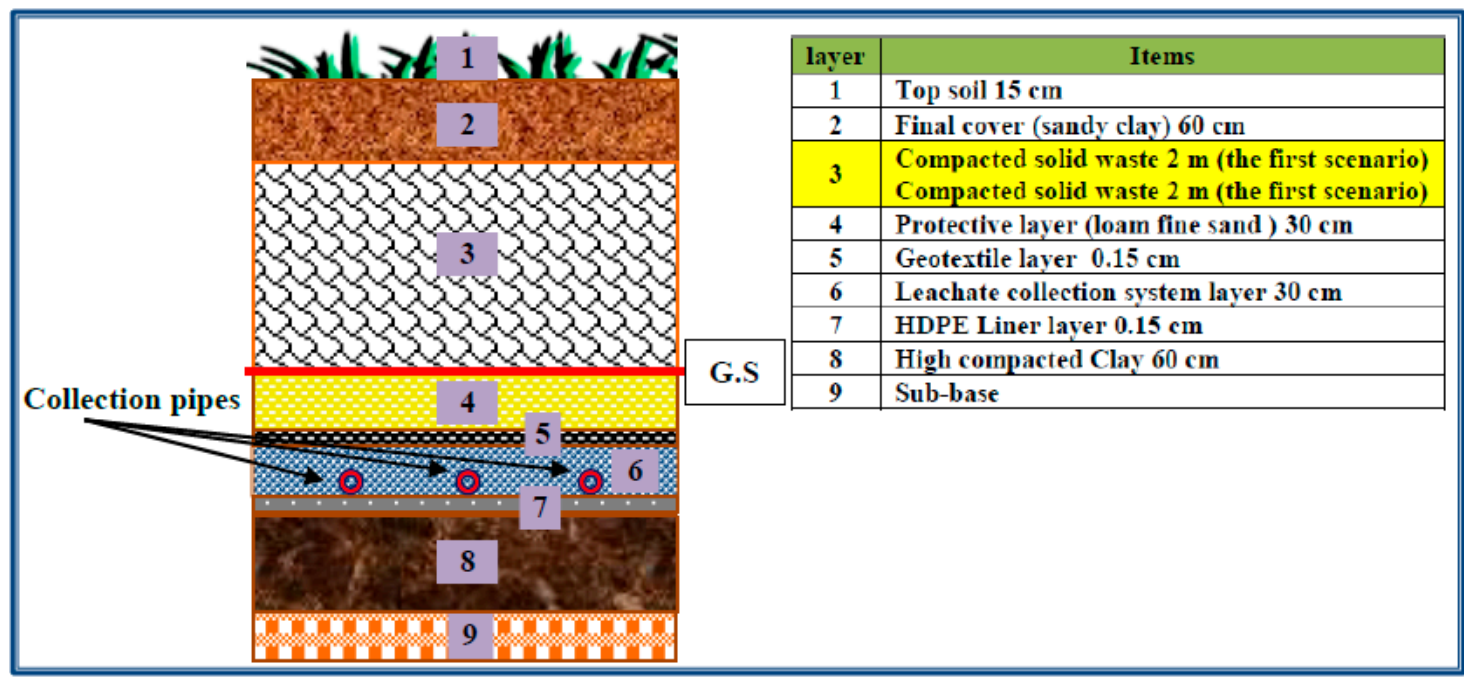

Figure 7. Profile of the suggested landfill design in the Hydrologic Evaluation of Landfill Performance (HELP) model.

Table 5. Characteristics of suggested soil layers data in the HELP model using the two scenarios.

\begin{tabular}{|c|c|c|c|c|c|c|c|c|c|}
\hline No. & Type & $\begin{array}{l}\text { Texture } \\
\text { Number } \\
\text { in HELP }\end{array}$ & Material & Thick (cm) & $\begin{array}{l}\text { Porosity } \\
\text { (vol./vol.) }\end{array}$ & $\begin{array}{l}\text { Field } \\
\text { Capacity } \\
\text { (vol./vol.) }\end{array}$ & $\begin{array}{l}\text { Wilting } \\
\text { Point } \\
\text { (vol./vol.) }\end{array}$ & $\begin{array}{l}\text { Initial Soil } \\
\text { Water } \\
\text { Content } \\
\text { (vol./vol.) }\end{array}$ & $\begin{array}{l}\text { Hydraulic } \\
\text { Conductivity } \\
\text { (cm/sec) }\end{array}$ \\
\hline 1 & $\mathrm{VPL}^{1}$ & 27 & $\begin{array}{l}\text { Moderate } \\
\text { compacted } \\
\text { Sandy Clay }\end{array}$ & 60 & 0.400 & 0.366 & 0.288 & 0.290 & $7.8 \times 10^{-7}$ \\
\hline 2 & VPL & 18 & Municipal Waste & $\begin{array}{c}200 \\
\text { (first scenario) }\end{array}$ & 0.671 & 0.292 & 0.077 & 0.292 & $1.0 \times 10^{-5}$ \\
\hline & VPL & 18 & Municipal Waste & $\begin{array}{c}400 \\
\text { (second scenario) }\end{array}$ & 0.671 & 0.292 & 0.077 & 0.292 & $1.0 \times 10^{-5}$ \\
\hline 3 & VPL & 5 & Loam Fine Sand & 30 & 0.457 & 0.131 & 0.058 & 0.131 & $1.0 \times 10^{-3}$ \\
\hline 4 & $\begin{array}{c}\mathrm{GL}^{2} \\
\left(\mathrm{FML}^{3}\right)\end{array}$ & 38 & Butyl Rubber & 0.15 & \multicolumn{4}{|c|}{$\begin{array}{l}\text { Pinhole Density }=0.40 \text { Holes } / \text { Hectare; Installation } \\
\text { Defects }=4.0 \text { Holes } / \text { Hectare; Placement Quality = } \\
\text { 3-Good; Drainage slope 3\%; Drainage length } 30 \mathrm{~m}\end{array}$} & $1.0 \times 10^{-12}$ \\
\hline 5 & LDL $^{4}$ & 21 & Gravel & 30 & 0.397 & 0.032 & 0.013 & 0.032 & $3.0 \times 10^{-1}$ \\
\hline 6 & LDL & 20 & Drain net & 0.5 & 0.850 & 0.010 & 0.005 & 0.010 & $1.0 \times 10^{+1}$ \\
\hline 7 & $\begin{array}{l}\mathrm{GM}^{5} \\
(\mathrm{FML})\end{array}$ & 35 & $\mathrm{HDPE}^{6}$ & 0.15 & \multicolumn{4}{|c|}{$\begin{array}{l}\text { Pinhole density }=0.40 \text { Holes } / \text { Hectare; Installation } \\
\text { defects }=4.0 \text { Holes } / \text { Hectare; Placement Quality = } \\
\text { 3-Good; Drainage; slope 3\%; Drainage length } 30 \mathrm{~m}\end{array}$} & $2.0 \times 10^{-13}$ \\
\hline 8 & BSL $^{7}$ & 16 & $\begin{array}{l}\text { High compacted } \\
\text { Clay }\end{array}$ & 60 & 0.427 & 0.418 & 0.367 & 0.427 & $1.0 \times 10^{-7}$ \\
\hline
\end{tabular}

${ }^{1}$ VPL: Vertical percolation layer; ${ }^{2}$ GT: Geotextile; ${ }^{3}$ FML: Flexible membrane liner; ${ }^{4}$ LDL: Lateral drainage layer; ${ }^{5}$ GM: Geomembrane; ${ }^{6}$ HDPE: High density polyethylene; ${ }^{7}$ BSL: Barrier soil liner layer.

\section{Results}

The extension files for all of the parameters were created within the model after inputting the weather data and the required information for the proposed soil layers of the landfill within the HELP model. The results of the suggested design for the selected landfills in Babylon Governorate can be summarized as follows:

\subsection{General Design and Evaporative Zone Data (Valid for 12 Years)}

The output results produced in the HELP model for the two scenarios can be seen in Table 6. The difference between the results of the two scenarios was in the value of initial water content in all of the layers, because the height of compacted waste in the first and second scenario were $2 \mathrm{~m}$ and $4 \mathrm{~m}$, respectively. 
Table 6. The general design and evaporative zone data using the two scenarios.

\begin{tabular}{ccc}
\hline & \multicolumn{2}{c}{ Data } \\
\cline { 2 - 3 } Items & First Scenario & Second Scenario \\
\hline Run-off curve number & 93.80 & 93.80 \\
Fraction of area allowing run-off & $100 \%$ & $100 \%$ \\
Soil evaporative zone depth & $50 \mathrm{~cm}$ & $50 \mathrm{~cm}$ \\
Initial water in evaporative zone & $14.50 \mathrm{~cm}$ & $14.50 \mathrm{~cm}$ \\
Upper limit of evaporative storage & $20.0 \mathrm{~cm}$ & $20.0 \mathrm{~cm}$ \\
Field capacity of evaporative zone & $18.3 \mathrm{~cm}$ & $18.3 \mathrm{~cm}$ \\
Lower limit of evaporative storage & $14.40 \mathrm{~cm}$ & $14.40 \mathrm{~cm}$ \\
Initial interception water & $0.0 \mathrm{~cm}$ & $0.0 \mathrm{~cm}$ \\
Initial water in all layers & $107.075 \mathrm{~cm}$ & $165.475 \mathrm{~cm}$ \\
Total subsurface inflow & $0.0 \mathrm{~mm} /$ year & $0.0 \mathrm{~mm} /$ year \\
\hline
\end{tabular}

The entered value of the soil evaporative zone depth in the HELP model was $50 \mathrm{~cm}$, which was based on field tests. The output results of the initial water in the evaporative zone was $14.5 \mathrm{~cm}$; this value resulted from multiplying the initial soil water content of the final cover layer $\left(0.29 \mathrm{~cm}^{3}\right.$ water $\left./ \mathrm{cm}^{3}\right)$ by the layer thickness $(50 \mathrm{~cm})$ [69]. The range values of evaporative storage were $14.4-20 \mathrm{~cm}$.

The values of the initial water in all of the layers using the first scenario and second scenario were $107.075 \mathrm{~cm}$ and $165.475 \mathrm{~cm}$, respectively. The increase in the initial water of the second scenario came from using the height of compacted waste of $4 \mathrm{~m}$ instead of the $2 \mathrm{~m}$ used in the first scenario through multiplying the additional thickness of compacted waste $(200 \mathrm{~cm})$ by the initial soil water content for this layer $\left(0.292 \mathrm{~cm}^{3}\right.$ water $\left./ \mathrm{cm}^{3}\right)$. In both scenarios, there was no inflow in the total subsurface for 12 successive years.

\subsection{Annual Data from 2005 to 2016}

In the HELP 3.95D model, the following annual data were calculated for the water behavior in the suggested soil layers between the years 2005 and 2016 using the following two scenarios. The summary of annual results values using two scenarios in the HELP model are as follows:

* The amount of collected water from lateral drainage layer (6) was zero.

* The values of the average head of water on top of the geotextile and the HDPE layers (4 and 7) were equal to zero.

* The values of water leakage through the geotextile and clay liner layers (4 and 8) were zero.

* The value of the interception water in the first and final year for the years 2005-2016 was zero.

The results of the annual data for precipitation, run-off, potential evapotranspiration, and actual evapotranspiration show that there was no difference in the results for the two scenarios (Table 7). However, the results were not the same for the annual water budget balance and soil water at the start and at end of each year between 2005 and 2016 (Table 8). Figure 8 shows the results of the annual data for precipitation, run-off, actual evapotranspiration, and changes in water storage for each year from 2005 to 2016. 


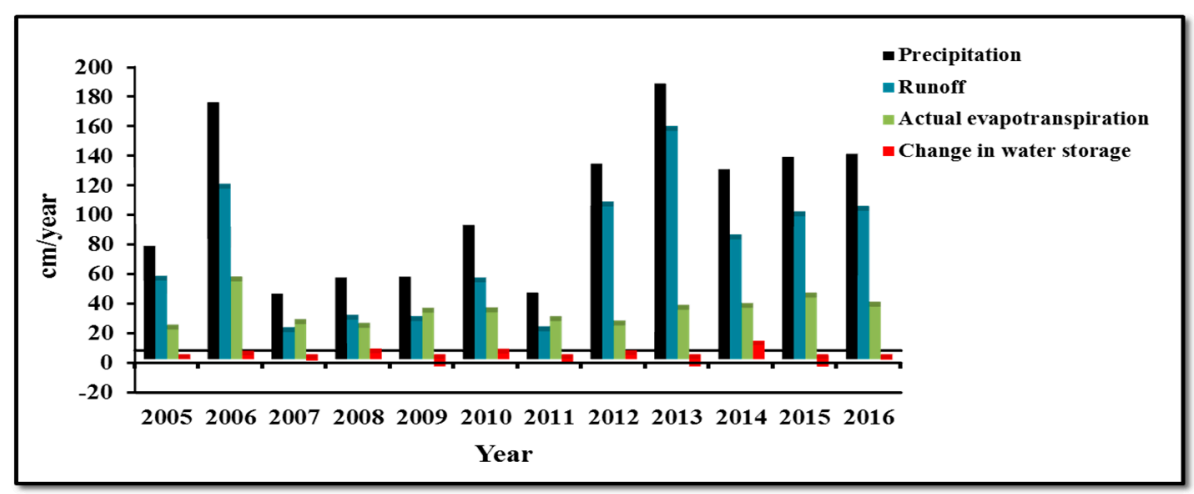

Figure 8. The annual data for precipitation, run-off, actual evapotranspiration, and change in water storage.

Table 7. Annual values for the weather parameters' data for the years 2005-2016 calculated within the HELP model using the two scenarios.

\begin{tabular}{|c|c|c|c|c|c|c|}
\hline \multirow{2}{*}{ Items } & \multicolumn{2}{|c|}{2005} & \multicolumn{2}{|c|}{2006} & \multicolumn{2}{|c|}{2007} \\
\hline & $\mathrm{mm}$ & $\%$ & $\mathbf{m m}$ & $\%$ & $\mathbf{m m}$ & $\%$ \\
\hline \multirow{5}{*}{$\begin{array}{c}\text { Precipitation } \\
\text { Run-off } \\
\text { Potential } \\
\text { evapotranspiration } \\
\text { Actual evapotranspiration }\end{array}$} & 73.20 & 100 & 170.30 & 100 & 41.00 & 100 \\
\hline & 53.11 & 72.55 & 115.25 & 67.67 & 18.31 & 44.67 \\
\hline & 1694.86 & & 1712.47 & & 1715.04 & \\
\hline & 20.05 & 27.39 & 52.62 & 30.90 & 23.73 & 57.87 \\
\hline & \multicolumn{2}{|c|}{2008} & \multicolumn{2}{|c|}{2009} & \multicolumn{2}{|c|}{2010} \\
\hline Precipitation & 51.80 & 100 & 52.40 & 100 & 87.30 & 100 \\
\hline Run-off & 26.68 & 51.51 & 25.74 & 49.12 & 51.93 & 59.49 \\
\hline $\begin{array}{c}\text { Potential } \\
\text { evapotranspiration }\end{array}$ & 1728.97 & & 1723.69 & & 1712.94 & \\
\hline \multirow[t]{2}{*}{ Actual evapotranspiration } & 21.25 & 41.02 & 31.47 & 60.05 & 31.70 & 36.31 \\
\hline & \multicolumn{2}{|c|}{2011} & \multicolumn{2}{|c|}{2012} & \multicolumn{2}{|c|}{2013} \\
\hline Precipitation & 41.70 & 100 & 128.80 & 100 & 182.90 & 100 \\
\hline Run-off & 18.87 & 45.25 & 103.21 & 80.13 & 154.30 & 84.36 \\
\hline $\begin{array}{c}\text { Potential } \\
\text { evapotranspiration }\end{array}$ & 1705.54 & & 1741.87 & & 1701.86 & \\
\hline \multirow[t]{2}{*}{ Actual evapotranspiration } & 25.83 & 61.94 & 22.89 & 17.77 & 33.40 & 18.26 \\
\hline & \multicolumn{2}{|c|}{2014} & \multicolumn{2}{|c|}{2015} & \multicolumn{2}{|c|}{2016} \\
\hline Precipitation & 125.00 & 100 & 133.40 & 100 & 135.40 & 100 \\
\hline Run-off & 81.04 & 64.83 & 96.59 & 72.41 & 100.27 & 74.06 \\
\hline $\begin{array}{c}\text { Potential } \\
\text { evapotranspiration }\end{array}$ & 1741.96 & & 1766.09 & & 1761.22 & \\
\hline Actual evapotranspiration & 34.71 & 27.77 & 41.75 & 31.29 & 35.48 & 26.20 \\
\hline
\end{tabular}


Table 8. Annual data values of water budget balance and soil water at the start and end of each year from 2005 to 2016 using the two scenarios.

\begin{tabular}{|c|c|c|c|c|c|c|c|c|}
\hline \multicolumn{9}{|c|}{ First Scenario } \\
\hline \multirow{2}{*}{ Items } & \multicolumn{2}{|c|}{2005} & \multicolumn{2}{|c|}{2006} & \multicolumn{2}{|c|}{2007} & \multicolumn{2}{|c|}{2008} \\
\hline & $\mathbf{m m}$ & $\%$ & $\mathbf{m m}$ & $\%$ & mm & $\%$ & $\mathbf{m m}$ & $\%$ \\
\hline Change in water storage & 0.04 & 0.06 & 2.43 & 1.43 & -1.04 & -2.54 & 3.87 & 7.47 \\
\hline * Soil water at start of year & $1110.05^{1}$ & & 1110.09 & & 1112.52 & & 1111.48 & \\
\hline \multirow[t]{2}{*}{ Soil water at end of year } & 1110.09 & & 1112.52 & & 1111.48 & & 1115.35 & \\
\hline & \multicolumn{2}{|c|}{2009} & \multicolumn{2}{|c|}{2010} & \multicolumn{2}{|c|}{2011} & \multicolumn{2}{|c|}{2012} \\
\hline Change in water storage & -4.81 & -9.17 & 3.67 & 4.20 & -3.0 & -7.19 & 2.7 & 2.10 \\
\hline Soil water at start of year & 1115.35 & & 1110.54 & & 1114.21 & & 1111.21 & \\
\hline \multirow[t]{2}{*}{ Soil water at end of year } & 1110.54 & & 1114.21 & & 1111.21 & & 1113.91 & \\
\hline & \multicolumn{2}{|c|}{2013} & \multicolumn{2}{|c|}{2014} & \multicolumn{2}{|c|}{2015} & \multicolumn{2}{|c|}{2016} \\
\hline Change in water storage & -4.8 & -2.62 & 9.25 & 7.40 & -4.94 & -3.70 & -0.35 & -0.26 \\
\hline Soil water at start of year & 1113.91 & & 1109.11 & & 1118.36 & & 1113.42 & \\
\hline Soil water at end of year & 1109.11 & & 1118.36 & & 1113.42 & & 1113.07 & \\
\hline \multicolumn{9}{|c|}{ Second Scenario } \\
\hline \multirow{2}{*}{ Items } & \multicolumn{2}{|c|}{2005} & \multicolumn{2}{|c|}{2006} & \multicolumn{2}{|c|}{2007} & \multicolumn{2}{|c|}{2008} \\
\hline & mm & $\%$ & mm & $\%$ & mm & $\%$ & mm & $\%$ \\
\hline Change in water storage & 0.04 & 0.06 & 2.43 & 1.43 & -1.04 & -2.54 & 3.87 & 7.47 \\
\hline * Soil water at start of year & $1694.05^{1}$ & & 1694.09 & & 1696.52 & & 1695.48 & \\
\hline \multirow[t]{2}{*}{ Soil water at end of year } & 1694.09 & & 1696.52 & & 1695.48 & & 1699.35 & \\
\hline & \multicolumn{2}{|c|}{2009} & \multicolumn{2}{|c|}{2010} & \multicolumn{2}{|c|}{2011} & \multicolumn{2}{|c|}{2012} \\
\hline Change in water storage & -4.81 & -9.17 & 3.67 & 4.20 & -3.0 & -7.19 & 2.7 & 2.10 \\
\hline Soil water at start of year & 1699.35 & & 1694.54 & & 1698.21 & & 1695.21 & \\
\hline \multirow[t]{2}{*}{ Soil water at end of year } & 1694.54 & & 1698.21 & & 1695.21 & & 1697.91 & \\
\hline & \multicolumn{2}{|c|}{2013} & \multicolumn{2}{|c|}{2014} & \multicolumn{2}{|c|}{2015} & 20 & \\
\hline Change in water storage & -4.8 & -2.62 & 9.25 & 7.40 & -4.94 & -3.70 & -0.35 & -0.26 \\
\hline Soil water at start of year & 1697.91 & & 1693.11 & & 1702.36 & & 1697.42 & \\
\hline Soil water at end of year & 1693.11 & & 1702.36 & & 1697.42 & & 1697.07 & \\
\hline
\end{tabular}

${ }^{1}$ The difference between soil water at the start of the year 2005 using the two scenarios $=540 \mathrm{~mm}$.

Generally, the results in the HELP model show that the largest amount of water comes from precipitation, and it was distributed over the surface into the run-off, actual evapotranspiration, and change in soil water storage between the beginning and the end for each year from 2005 to 2016 . Consequently, no water percolated into the suggested soil layers (under the ground surface), which were designed for the selected landfill sites.

Annual values for the weather parameters' data for the years 2005-2016 were calculated within the HELP model. The rainfall was separated as run-off, potential evapotranspiration, and change in water storage. For example: in 2005, the value of precipitation was $73.2 \mathrm{~mm}(100 \%)$, run-off was $53.11 \mathrm{~mm}(72.55 \%)$, actual evapotranspiration was $20.05 \mathrm{~mm}(27.39 \%)$, and change in water storage was $0.04 \mathrm{~mm}(0.06 \%)$.

The soil water at the start of the year $2005(1110.05 \mathrm{~mm})$ came from adding the first value of rainfall in $2005(40 \mathrm{~mm})$ to the initial water content in all of the soil layers $(1070.05 \mathrm{~mm})$. The soil water at the end of each year was estimated in the HELP model based on the value of the water storage change. For example, the soil water at the end of the year 2005 was $1110.05 \mathrm{~mm}$. This value is the result of adding the value of water storage change in $2005(0.04 \mathrm{~mm})$ to the soil water at the start of the year 2005 (1110.09 mm). 
The increase in the soil water at the start of each year in the second scenario compared with the value of the first scenario arose as a result of adding a layer of waste $(2000 \mathrm{~mm})$. For example, the difference between the soil water at the start of the year 2005 using the two scenarios was $540 \mathrm{~mm}$. This value resulted from multiplying the waste initial water content $\left(0.292 \mathrm{~mm}^{3}\right.$ water $\left./ \mathrm{mm}^{3}\right)$ by the waste thickness (2000 $\mathrm{mm})$.

The volume of precipitation, run-off, and actual evapotranspiration for each year was calculated by multiplying the value of each parameter by the area of the landfill site. For example, Table 9 shows the value and volume of these parameters in the Al-Qasim district, Babylon Governorate. The area of landfills in the Al-Qasim district is $90,000 \mathrm{~m}^{2}$.

Table 9. The value and volume of precipitation, run-off, and actual evapotranspiration in the Al-Qasim district, Babylon Governorate.

\begin{tabular}{|c|c|c|c|c|c|c|}
\hline \multirow{2}{*}{ Items } & \multicolumn{2}{|c|}{2005} & \multicolumn{2}{|c|}{2006} & \multicolumn{2}{|l|}{2007} \\
\hline & m & $\mathrm{m}^{3}$ & $\mathbf{m m}$ & $\mathrm{m}^{3}$ & $\mathrm{~mm}$ & $\mathrm{~m}^{3}$ \\
\hline Precipitation & $73.2 \times 10^{-3}$ & 65,880 & $170.3 \times 10^{-3}$ & 153,270 & $41 \times 10^{-3}$ & 36,899 \\
\hline Run-off & $53.11 \times 10^{-3}$ & 47,802 & $115.25 \times 10^{-3}$ & 103,721 & $18.31 \times 10^{-3}$ & 16,483 \\
\hline \multirow[t]{2}{*}{ Actual evapotranspiration } & $20.05 \times 10^{-3}$ & 18,039 & $52.62 \times 10^{-3}$ & 47,358 & $23.73 \times 10^{-3}$ & 21,352 \\
\hline & \multicolumn{2}{|c|}{2008} & \multicolumn{2}{|c|}{2009} & \multicolumn{2}{|l|}{2010} \\
\hline Precipitation & $51.8 \times 10^{-3}$ & 46,62 & $52.40 \times 10^{-3}$ & 47,160 & $87.30 \times 10^{-3}$ & 78,570 \\
\hline Run-off & $26.68 \times 10^{-3}$ & 24,013 & $25.74 \times 10^{-3}$ & 23,166 & $51.93 \times 10^{-3}$ & 46,742 \\
\hline \multirow[t]{2}{*}{ Actual evapotranspiration } & $21.25 \times 10^{-3}$ & 19,121 & $31.47 \times 10^{-3}$ & 28,321 & $31.7 \times 10^{-3}$ & 28,526 \\
\hline & \multicolumn{2}{|c|}{2011} & \multicolumn{2}{|l|}{2012} & \multicolumn{2}{|l|}{2013} \\
\hline Precipitation & $41.7 \times 10^{-3}$ & 37,530 & $128.8 \times 10^{-3}$ & 115,920 & $182.9 \times 10^{-3}$ & 164,610 \\
\hline Run-off & $18.87 \times 10^{-3}$ & 16,984 & $103.21 \times 10^{-3}$ & 92,887 & $154.3 \times 10^{-3}$ & 138,868 \\
\hline \multirow[t]{2}{*}{ Actual evapotranspiration } & $25.83 \times 10^{-3}$ & 23,250 & $22.89 \times 10^{-3}$ & 20,605 & $33.4 \times 10^{-3}$ & 30,057 \\
\hline & \multicolumn{2}{|c|}{2014} & \multicolumn{2}{|l|}{2015} & \multicolumn{2}{|l|}{2016} \\
\hline Precipitation & $125 \times 10^{-3}$ & 112,500 & $133.4 \times 10^{-3}$ & 120,060 & $135.4 \times 10^{-3}$ & 121,860 \\
\hline Run-off & $81.04 \times 10^{-3}$ & 72,933 & $96.59 \times 10^{-3}$ & 86,930 & $100.27 \times 10^{-3}$ & 90,245 \\
\hline Actual evapotranspiration & $34.71 \times 10^{-3}$ & 31,240 & $41.75 \times 10^{-3}$ & 37,574 & $35.48 \times 10^{-3}$ & 31,931 \\
\hline
\end{tabular}

\subsection{Peak Daily Values from 2005 to 2016}

In the HELP model, the peak daily values were calculated for the water behavior in the suggested soil layers and for different parameters over all of the years from 2005 to 2016 using two scenarios. The peak daily values of precipitation and run-off were $98.6 \mathrm{~mm}$ and $97.19 \mathrm{~mm}$, respectively. The maximum value of water content in the evaporation zone was 0.315 (vol./vol.), while the minimum value was 0.288 (vol./vol.). The peak daily value of (i) the amount collected water from lateral drainage layer (6); (ii) the values of the average head of water on top of the geotextile and the HDPE layers ( 4 \& 7); (iii) the values of water leakage through the geotextile and clay liner layers (4 and 8) were all zero. The maximum head of water on top of the layers was computed according to McEnroe's equations [70]. In the HELP model, there was no difference in the results for the peak daily values using the two scenarios.

\subsection{Average Monthly Values for the Years 2005-2016}

In the HELP model, the values of average monthly data were calculated for the years from 2005 to 2016 using the two scenarios, and similar values were produced in the both scenarios, as shown in Table 10. These results included the following parameter values: precipitation, run-off, potential evapotranspiration, and actual evapotranspiration. 
Table 10. Average monthly values (mm) for the years 2005-2016 using two scenarios.

\begin{tabular}{ccccccc}
\hline Items & JAN. & FEB. & MAR. & APR. & MAY. & JUN. \\
\hline Precipitation & 17.17 & 13.38 & 11.27 & 9.20 & 4.06 & 0.0 \\
Run-off & 11.54 & 8.66 & 7.10 & 4.99 & 2.12 & 0.0 \\
Potential evapotranspiration & 52.36 & 66.91 & 107.56 & 164.21 & 204.09 & 230.20 \\
Actual evapotranspiration & 4.5 & 4.72 & 4.25 & 5.55 & 3.44 & 0.62 \\
\hline & JUL. & AUG. & SEP. & OCT. & NOV. & DEC. \\
\hline Precipitation & 0.0 & 0.0 & 0.23 & 6.57 & 21.67 & 18.38 \\
Run-off & 0.0 & 0.0 & 0.02 & 4.22 & 17.16 & 14.57 \\
Potential evapotranspiration & 252.90 & 227.96 & 181.71 & 116.77 & 66.59 & 54.27 \\
Actual evapotranspiration & 0.01 & 0.0 & 0.16 & 0.62 & 2.67 & 3.70 \\
\hline
\end{tabular}

The values of the average monthly water state within the soil layers for the suggested landfill design from 2005 to 2016, using two scenarios, was as follows:

* The lateral drainage amount that collected water from layer (6) was zero.

* The values of water percolation through the geotextile and clay liner layers (4) and (8) were equal to zero.

* The values of the daily average head of water on top of layers (4) and (7) were zero.

\subsection{Average Annual Values for the Years 2005-2016}

The current model, the average annual values $(\mathrm{mm})$, and their proportions were calculated for the years 2005-2016. Using both scenarios, the values of water percolation through the layers (4) and (8), the average head on top of layers (4) and (7), and the lateral drainage of water collected from layer (6) were zero. In the HELP model, using the two scenarios, the average annual value of precipitation was $101.93 \mathrm{~mm}$. This value was attributed to run-off of $71.36 \mathrm{~mm}(70 \%)$, the actual evapotranspiration of $30.32 \mathrm{~mm}(29.75 \%)$, and a change in water storage of $0.25(0.25 \%)$. The average annual value of potential evapotranspiration that was calculated in the HELP model was $1725.54 \mathrm{~mm}$.

\subsection{Final Water Storage of Layers at the End of 2016}

The final storage of water in all of the layers for the suggested design of the landfills at the end of 2016 was calculated within the HELP model, with eight layers being used in the first scenario, and 10 layers being used in the second scenario. The volumetric content of soil water storage was also calculated in this model, where it was defined as the ratio of water volume in a specific soil layer to the total volume that is occupied by the voids which are filled with air, water, and soil.

The results for the final water storage at the end of 2016 using the first scenario and the second scenario can be seen in Table 11. The increase in final water storage in the second scenario when compared with the first scenario arose as a result of adding a layer of waste (2) $\mathrm{m}$, with the values of water storage in the waste layer being $58.4 \mathrm{~cm}$.

Using the two scenarios, the total initial water and the final total water in all of the layers were $107.075 \mathrm{~cm}$ and $165.475 \mathrm{~cm}$, respectively. The total initial water and the final total water in all of the layers using the two scenarios were $107.377 \mathrm{~cm}$ and $165.777 \mathrm{~cm}$, respectively. The difference between the initial and final soil water for all of the layers in both scenarios was $0.302 \mathrm{~cm}$. The increase in the final water storage for each scenario at the end of 2016 resulted from adding the amount of water to the final cover (layer 1) that resulted from the difference between the soil water at start of year 2005 $(1694.05 \mathrm{~mm})$ and the soil water at end of year $2016(1697.07 \mathrm{~mm})$. The interception water was zero, where the total subsurface inflow was $0.0 \mathrm{~mm} /$ year. 
Table 11. Final water storage in all of the soil layers at the end of the year 2016 using the two scenarios.

\begin{tabular}{|c|c|c|c|c|}
\hline \multirow{2}{*}{ Layer } & \multicolumn{2}{|c|}{ The First Scenario } & \multicolumn{2}{|c|}{ The Second Scenario } \\
\hline & $\begin{array}{l}\text { Final Water } \\
\text { Storage }(\mathrm{cm})\end{array}$ & $\begin{array}{c}\text { Volumetric } \\
\text { Content (vol./vol.) }\end{array}$ & $\begin{array}{l}\text { Final Water } \\
\text { Storage }(\mathrm{cm})\end{array}$ & $\begin{array}{c}\text { Volumetric } \\
\text { Content (vol./vol.) }\end{array}$ \\
\hline 1 & 18.462 & 0.308 & 18.462 & 0.308 \\
\hline 2 & 58.400 & 0.292 & 116.800 & 0.292 \\
\hline 3 & 3.930 & 0.131 & 3.930 & 0.131 \\
\hline 4 & 0.0 & 0.0 & 0.0 & 0.0 \\
\hline 5 & 0.005 & 0.010 & 0.005 & 0.010 \\
\hline 6 & 0.960 & 0.032 & 0.960 & 0.032 \\
\hline 7 & 0.0 & 0.0 & 0.0 & 0.0 \\
\hline 8 & 25.620 & 0.427 & 25.620 & 0.427 \\
\hline \multicolumn{3}{|c|}{ Total initial water in all layers $=\mathbf{1 0 7 . 0 7 5}$} & \multicolumn{2}{|c|}{ Total initial water in all layers $=\mathbf{1 6 5 . 4 7 5}$} \\
\hline \multicolumn{3}{|c|}{$\begin{array}{l}\text { The difference between the initial and final } \\
\text { soil water }=0.302 \mathrm{~cm}\end{array}$} & \multicolumn{2}{|c|}{$\begin{array}{l}\text { The difference between the initial and } \\
\text { final soil water }=0.302 \mathrm{~cm}\end{array}$} \\
\hline \multicolumn{3}{|c|}{ Total water in all layers $=\mathbf{1 0 7 . 3 7 7}$} & \multicolumn{2}{|c|}{ Total water in all layers = $\mathbf{1 6 5 . 7 7 7}$} \\
\hline \multicolumn{3}{|c|}{ Interception water $=0.0$} & \multicolumn{2}{|c|}{ Interception water $=0.0$} \\
\hline \multicolumn{3}{|c|}{ Total subsurface inflow $=0.0 \mathrm{~mm} / \mathrm{yr}$. } & \multicolumn{2}{|c|}{ Total subsurface inflow $=0.0 \mathrm{~mm} / \mathrm{yr}$. } \\
\hline
\end{tabular}

\section{Conclusions}

Adopting a suitable design for landfill in a particular area that has special conditions (such as shallow groundwater depth and hot climate) is necessary in order to prevent the contamination of groundwater by the leachate produced from a landfill site. In addition, for any landfill site, an adequate design should be implemented to fulfill the environmental requirements and protect humans from the negative effects that result from landfills. In the current study area (Babylon Governorate), there are no systematic sites for landfill that follow the environmental and scientific criteria, even though the groundwater depth in the governorate is shallow. The first step involved selecting the most suitable sites for landfill in each Qadhaa in the Babylon Governorate using GIS software and a multi-criteria decision making method, as in a previous study. Then, the best suggested design for the selected landfill sites was obtained. Then, the Hydrologic Evaluation of Landfill Performance (HELP 3.95D) model was used to calculate the amounts of potential and actual evapotranspiration, run-off, collected lateral drainage of leachate, and leakage or percolation leachate through the base liner of landfill designs. This model takes into consideration weather factors (precipitation, temperature, solar radiation, and evapotranspiration) and the properties of the suggested soil layers to produce a perfect design for landfills.

In the suggested design, the compacted solid waste was placed over the surface because the groundwater depth in all of the selected landfill sites was shallow. Two scenarios were used to select the optimum height for the compacted solid waste at the site. The height of the compacted solid waste in the first scenario was $2 \mathrm{~m}$ (one lift of waste). A compacted waste height of $4 \mathrm{~m}$ was used in the second scenario. The compacted solid waste layer was covered with the final cover layer of moderate compacted sandy clay with a thickness of $60 \mathrm{~cm}$, and also after a specific period when the settlement of the sandy clay layer caused by the decomposition of organic material of the solid waste had stopped. The final cover will be replaced with a final $60-\mathrm{cm}$ sealing clay layer. Then, the final cover will be covered with a $15 \mathrm{~cm}$ layer of topsoil to support vegetation growth.

Under the ground surface, a protective $30 \mathrm{~cm}$ layer of loam fine sand was placed directly under the compacted solid waste layer. The non-wave geotextile layer $(150 \mathrm{~mm})$ was placed beneath the protective layer. The lateral drainage layer was placed under the geotextile layer to a thickness of $30 \mathrm{~cm}$. After that, the clay liner layer was placed under the lateral drainage layer to a thickness of $60 \mathrm{~cm}$. Finally, the compacted, 20-cm thick sub-base was put under the clay liner layer.

Perimeter drainage around the landfilling and treatment facilities of the leachate is necessary for the management of run-on and run-off stormwater. Therefore, the perimeter berm should be built 
around the landfill site with an anchor trench that is constructed along the connecting line of the outside edge of the perimeter berm.

The results showed that the highest amount of precipitation was dispersed on the surface as run-off and actual evapotranspiration. There was no leachate within the layers underground (below the surface sealing), where the values of water percolation through the geotextile and clay liner layers were zero. The amount of collected water that drained from the lateral drainage layer (the leachate volume on the drainage layer above the geomembrane) was equal to zero. Thus, the suggested design for the selected landfill sites was seen to be fit for purpose.

In this study, using the two scenarios, the average annual precipitation value was $101.93 \mathrm{~mm}$ over the years from 2005 to 2016 . The average annual value of precipitation was dispersed by run-off, with a value of $71.36 \mathrm{~mm}(70 \%)$, and by actual evapotranspiration, with a value of $30.32 \mathrm{~mm}(29.75 \%)$.

The increase in the final soil water at the end of 2016 for all of the layers in both scenarios was $0.302 \mathrm{~cm}$. This resulted from adding the amount of water to the final cover.

The soil water at the start of the year 2005 came from adding the first value of rainfall in 2005 to the initial water content in all of the soil layers. In the HELP model, the soil water at the end of each year was estimated based on the value of water storage change.

The increase in final water storage from $54.4 \mathrm{~cm}$ in the first scenario to $116.8 \mathrm{~cm}$ in the second scenario resulted from adding another layer of waste, which raised the height from $2 \mathrm{~m}$ to $4 \mathrm{~m}$.

The cumulative loads that resulted from using $4 \mathrm{~m}$ of height waste, the final soil cover $(60 \mathrm{~cm})$, and the daily covers of soil $(15 \mathrm{~cm})$ are acceptable. The bearing capacity for the soils of the selected sites was $50 \mathrm{KN} / \mathrm{m}^{2}$, according to the Iraqi Ministry of Housing \& Construction (2016).

The second scenario of placing $4 \mathrm{~m}$ of compacted solid waste instead of $2 \mathrm{~m}$ in the first scenario will extend the life span of each selected site from 10 to 18 years (from 2030 to 2038). In addition, the required area for landfill will be reduced by $50 \%$ when compared with using a waste layer height equal to $2 \mathrm{~m}$.

Future work will use the HELP model to collect data related to the lateral drainage of leachate and leakage or percolation leachate through the base liner of landfill designs without placing the final cover. These future studies will also use layers that are similar to those suggested in the experimental model to estimate the percolation leachate through the base liner.

Acknowledgments: University of Babylon, Iraq provided the first author a scholarship to do his PhD degree at Lulea University of Technology (LTU). LTU provided all the labs, computer facilities and software for the authors. The authors would like to gratefully thank Amer Al-Musawi for providing some of information to authors.

Author Contributions: The first author did the field, lab and modeling as well as writing the paper. Other authors, helped the first author in discussing the results and discussions.

Conflicts of Interest: The authors declare no conflict of interest.

\section{References}

1. Scott, J.; Beydoun, D.; Amal, R.; Low, G.; Cattle, J. Landfill management, leachate generation, and leach testing of solid wastes in Australia and overseas. Crit. Rev. Environ. Sci. Technol. 2005, 35, 239-332. [CrossRef]

2. Hart, J. Geophysical Investigation of the Clay Cap at a Closed Landfill in Southwestern Ontario, Canada. Master's Thesis, Department of Earth and Environmental Sciences, University of Windsor, Windsor, ON, Canada, 2013; p. 81.

3. Asefi, H.; Lim, S. A novel multi-dimensional modeling approach to integrated municipal solid waste management. J. Clean. Prod. 2017, 166, 1131-1143. [CrossRef]

4. Aird, J. Challenges at MSW landfill sites: From daily cover to drainage. Erosion Control 2017, $24,16-21$.

5. Ragazzi, M.; Catellani, R.; Rada, E.C.; Torretta, V.; Salazar-Valenzuela, X. Management of urban wastewater on one of the Galapagos Islands. Sustainability 2016, 8, 208. [CrossRef]

6. Meegoda, J.N.; Hettiarachchi, H.; Hettiaratchi, P. Landfill design and operation. In Sustainable Solid Waste Management; American Society of Civil Engineers: Reston, VA, USA, 2016; pp. 577-604. 
7. Renou, S.; Givaudan, J.G.; Poulain, S.; Dirassouyan, F.; Moulin, P. Landfill leachate treatment: Review and opportunity. J. Hazard. Mater. 2008, 150, 468-493. [CrossRef] [PubMed]

8. Ghiani, G.; Laganà, D.; Manni, E.; Musmanno, R.; Vigo, D. Operations research in solid waste management: A survey of strategic and tactical issues. Comput. Oper. Res. 2014, 44, 22-32. [CrossRef]

9. Alslaibi, T.M.; Abustan, I.; Mogheir, Y.K.; Afifi, S. Quantification of leachate discharged to groundwater using the water balance method and the Hydrologic Evaluation of Landfill Performance (HELP) model. Waste Manag. Res. 2013, 31, 50-59. [CrossRef] [PubMed]

10. Brockerhoff, M.P. An Urbanizing World; Population Reference Bureau (PRB): Washington, DC, USA, 2000; Volume 55, pp. 1-48.

11. Proske, H.; Vlcko, J.; Rosenbaum, M.S.; Dorn, M.; Culshaw, M.; Marker, B. Special purpose mapping for waste disposal sites. Bull. Eng. Geol. Environ. 2005, 64, 1-54. [CrossRef]

12. Moeinaddini, M.; Khorasani, N.; Danehkar, A.; Darvishsefat, A.A.; Zienalyan, M. Siting MSW Landfill Using Weighted Linear Combination and Analytical Hierarchy Process (AHP) Methodology in GIS Environment (Case Study: Karaj). Waste Manag. 2010, 30, 912-920. [CrossRef] [PubMed]

13. Munawar, E.; Fellner, J. Guidelines for Design and Operation of Municipal Solid Waste Landfills in Tropical Climates; Technische Universität Wien: Vienna, Austria, 2013; p. 28.

14. Joseph, K.; Nagendran, R.; Palanivelu, K.; Thanasekaran, K.; Visvanathan, C. Dumpsite Rehabilitation and Landfill Mining; Anna University: Chennai, India, 2004; p. 65. Available online: http://saahas.org/wpcontent-saahas / uploads/2015/02/Landfills3.pdf (accessed on 5 October 2017).

15. World Health Organization. Protecting Groundwater for Health: Managing the Quality of Drinking-Water Sources; World Health Organization: Geneva, Switzerland, 2006.

16. Allen, A. Containment Landfills: The myth of sustainability. Eng. Geol. 2001, 60, 3-19. [CrossRef]

17. Gray, D.A.; Mather, J.D.; Harrison, I.B. Review of groundwater pollution from waste disposal sites in England and Wales, with provisional guidelines for future site selection. Q. J. Eng. Geol. Hydrogeol. 1974, 7, 181-196. [CrossRef]

18. Bauerle, M. Adapting the Hydrologic Evaluation of Landfill Performance (H.E.L.P.) Model to the Climatic and Soil Characteristics of Queensland. Master Thesis, School of Earth, Environmental and Biological Sciences, Science and Engineering Faculty, Queensland University of Technology, Brisbane, Australia, 2016; p. 217.

19. O'Leary, P.; Walsh, P. Decision Maker's Guide to Solid Waste Management; Solid and Hazardous Waste Education Center, University Of Wisconsin: Madison, WI, USA, 1995; Volume II, p. 372.

20. Alslaibi, T.; Mogheir, Y.; Afifi, S. Analysis of landfill components in estimating the percolated leachate to groundwater using the HELP model. Water Sci. Technol. 2010, 62, 1727-1734. [CrossRef] [PubMed]

21. Manitoba Sustainable Development, Leachate Management at a Waste Management Facility. Manitoba.ca, Sustainable Development, Environmental Compliance and Enforcement. 2016; p. 6. Available online: https://www.gov.mb.ca/sd/envprograms/swm/pdf/leachate_management_wdg.pdf (accessed on 5 October 2017).

22. Inanç, B.; Çalh, B.; Saatçi, A. Characterization and anaerobic treatment of the sanitary landfill leachate in Istanbul. Water Sci. Technol. 2000, 41, 223-230. [PubMed]

23. Li, R. Management of Landfill Leachate. Master Thesis, TAMK University of Applied Sciences, Tampere, Finland, 2009; p. 45.

24. Malina, J.F.; Pohland, F.G. Design of anaerobic processes for the treatment of industrial and municipal wastes. Water Qual. Manag. 1996, 7, 169-175.

25. Ireland Environmental Protection Agency (Ireland EPA). Landfill Manuals Landfill Site Design; Environmental Protection Agency: Limerick, Ireland, 2000; p. 154.

26. Hughes, K.; Christy, A.; Heimlich, J. Landfill Types and Liner Systems; Ohio State University Extension Fact Sheet CDFS-138-05; The Ohio State University: Columbus, OH, USA, 2008; p. 4.

27. Iraqi Ministry of Water Resources. General Commission for Groundwater; Internal Reports; Iraqi Ministry of Water Resources: Baghdad, Iraq, 2015.

28. Berger, K.U. On the current state of the Hydrologic Evaluation of Landfill Performance (HELP) model. Waste Manag. 2015, 38, 201-209. [CrossRef] [PubMed] 
29. Berger, K.U.; Schroeder, P.R. The Hydrologic Evaluation of Landfill Performance (HELP) Model, User's Guide for HELP-D (Version 3.95D), 6th revised edition for version HELP 3.95D; Institute of Soil Science, University of Hamburg: Hamburg, Germany, 2013; p. 74.

30. Schroeder, P.R.; Dozier, T.S.; Zappi, P.A.; McEnroe, B.M.; Sjostrom, J.W.; Peyton, R.L. The Hydrologic Evaluation of Landfill Performance (HELP) Model; Engineering Documentation for Version 3; U.S. Environmental Protection Agency Office of Research and Development: Washington, DC, USA, 1994; p. 126.

31. Al-Taie, L. Performance of Clay Liners in Near-Surface Repositories in Desert Climate. Ph.D. Thesis, Soil Mechanics and Foundation Engineering, Lulea University of Technology, Lulea, Sweden, 2014.

32. Frikha, Y.; Fellner, J.; Zairi, M. Leachate generation from landfill in a semi-arid climate: A qualitative and quantitative study from Sousse, Tunisia. Waste Manag. Res. 2017, 35, 940-948. [CrossRef] [PubMed]

33. Iraqi Ministry of Municipalities and Public Works. Structural Plan of Babylon Governorate; The Directorate General of Urban Planning, Information Analysis Report (Revised); Stage 2; Iraqi Ministry of Municipalities and Public Works: Baghdad, Iraq, 2009; p. 223.

34. Iraqi Ministry of Planning. Records of Directorate of Census Babylon; Internal Reports; Iraqi Ministry of Planning: Baghdad, Iraq, 2016.

35. Chabuk, A.; Al-Ansari, N.; Hussain, H.M.; Knutsson, S.; Pusch, R. Present status of solid waste management at Babylon Governorate, Iraq. Engineering 2015, 7, 408-423. [CrossRef]

36. Iraqi Ministry of Municipalities and Public Works. Records of Directorate of Babylon Municipalities; Internal Reports; Iraqi Ministry of Municipalities and Public Works: Babylon, Iraq, 2013.

37. Iraqi Ministry of Municipalities and Public Works. Babylon Plant for Recycling and Compressing Waste, Records of Directorate of Al-Hillah Municipality, Babylon; Internal Reports; Iraqi Ministry of Municipalities and Public Works: Baghdad, Iraq, 2016.

38. Alnajjar, A.Y. Solid Waste Management Scenario in Iraq, Middle East, Solid Waste Management, EcoNENA. 2016. Available online: http://www.ecomena.org/tag/solid-waste-management-in-iraq (accessed on 5 October 2017).

39. Iraqi Ministry of Municipalities and Public Works. Records of Directorate of Babylon Municipalities; Internal Reports; Iraqi Ministry of Municipalities and Public Works: Babylon, Iraq, 2015.

40. Al Khalidy, K.S.; Chabuk, A.J.; Kadhim, M.M. Measurement of Lead Pollution in the Air of Babylon Governorate, Iraq during Year 2010. World Acad. Sci. Eng. Technol. 2012, 6, 830-833.

41. Consulting Engineering Bureau College of Engineering. Hydrological Study of Ancient Babylon Site; Final Report; Baghdad University: Baghdad, Iraq, 2012.

42. Iraqi Ministry of Transportation Constitutions. Iraqi Meteorological Organization \& Seismology; Internal Reports; Iraqi Ministry of Transportation Constitutions: Baghdad, Iraq, 2017.

43. Al-Ansari, N.A.; Abdellatif, M.; Ali, S.; Knutsson, S. Long Term Effect of Climate Change on Rainfall in Northwest Iraq. Cent. Eur. J. Eng. 2014, 4, 250-263. [CrossRef]

44. Osman, Y.; Abdellatif, M.; Al-Ansari, N.A.; Knutsson, S.; Aljawad, S.B. Climate Change and Future Precipitation in Arid Environment of Middle East: Case study of Iraq. J. Environ. Hydrol. 2017, 25, 1-18.

45. Chabuk, A.; Al-Ansari, N.; Hussain, H.M.; Kamaleddin, S.; Knutsson, S.; Pusch, R.; Laue, J. Combining GIS Applications and Method of Multi-Criteria Decision-Making (AHP) for Landfill Siting in Al-Hashimiyah Qadhaa, Babylon, Iraq. Sustainability 2017, 9, 1932. [CrossRef]

46. Iraqi Ministry of Municipalities and Public Works. Directorate of Sewage Babylon; Internal Reports; Iraqi Ministry of Municipalities and Public Works: Baghdad, Iraq, 2013.

47. Jassim, S.Z.; Goff, J.C. Geology of Iraq; Dolin, Prague and Moravain Museum: Brno, Czech Republic, 2006; p. 356.

48. Iraqi Ministry of Housing \& Construction. National Center for Construction Laboratories and Research; Internal Report; Iraqi Ministry of Housing \& Construction: Babylon, Iraq, 2016.

49. Chabuk, A.; Al-Ansari, N.; Hussain, H.M.; Kamaleddin, S.; Knutsson, S.; Pusch, R.; Laue, J. Soil Characteristics in Selected Landfill Sites in the Babylon Governorate, Iraq. J. Civ. Eng. Archit. 2017, 11, 348-363. [CrossRef]

50. Oni, O.A. An Investigation into the Impact of Sequential Filling on Properties of Emplaced Refuse Lifts and Moisture Stored in a Municipal Solid Waste Landfill. Ph.D. Thesis, Department of Civil and Environmental Engineering, University of Southampton, Southampton, UK, 2000; p. 226. 
51. Chabuk, A.; Al-Ansari, N.; Hussain, H.M.; Kamaleddin, S.; Knutsson, S.; Pusch, R.; Laue, J. Landfills Site Selection in Babylon, Iraq. J. Earth Sci. Geotech. Eng. 2017, 7, 1-15.

52. British Columbia. Landfill Criteria for Municipal Solid Waste, 2nd ed.; British Columbia Ministry of Environment: Fort St. John, BC, Canada, 2016; p. 76.

53. Wihan Visser Jan Palm Consulting Engineers; Thorsten Aab WSP Group Africa. Guidelines to the Design of a Landfill Facility; Landfill Interest Group: Seminar Session 2: Overview of Landfill Facility Design and Associated Infrastructure; IWMSA: Johannesburg, South Africa, 2014.

54. Bagchi, A. Design of Landfills and Integrated Solid Waste Management, 3rd ed.; John Wiley \& Sons: Hoboken, NJ, USA, 2004; p. 696.

55. Swedish Environmental Protection Agency. Landfilling of Waste, with Guidelines to the Ordinance (2001:512) on the Landfill of Waste and to Chapter 15, 34 § of the Environmental Code (1998:808); Swedish Environmental Protection Agency: Stockholm, Sweden, 2004.

56. Rowe, R.K.; Sangam, H.P. Durability of HDPE geomembranes. Geotext. Geomembr. 2002, 20, 77-95. [CrossRef]

57. Joyal, C. New Solid Waste Facility-Preliminary Design Report; Final Report; Department of Public Works and Engineering, Dillon Consulting Limited: Yellowknife, NT, Canada, 2006; p. 77.

58. SCIP Engineering Group. Conceptual Design of a New Waste Disposal Facility for Lesedi Local Municipality, Heidelberg; Report No. (10612452-12628-7); Golder Associates: Mississauga, ON, USA, 2014; p. 45.

59. Special Inspector General for Iraq Reconstructive. Baghdad Municipal Solid Waste, Memorandum for Commanding General, Multi-National Forces_Iraq; Report on Project Assessment of the Baghdad Municipal Solid Waste Landfill; Baghdad Municipal Solid Waste Landfill: Baghdad, Iraq, 2006; p. 33.

60. New South Wales Environment Protection Authority. Environmental Guidelines Solid Waste Landfills, 2nd ed.; New South Wales Environment Protection Authority: Sydney, Australia, 2016; p. 95.

61. Abu-Rizaiza, A.S.; Abdul Aziz, H. The Proposed Design and Tendering for the New Phase of Landfill at Southern Makkah Disposal Site: Phase 1; Design Report; Department of Environmental Sciences, King Abdulaziz University: Jeddah, Saudi Arabia; Research Cluster on Waste Management, School of Civil Engineering, Universiti Sains Malaysia: Gelugor, Malaysia, 2011; p. 80.

62. Japan International Coorperation Agency. The Study on the Safe Closure and Rehabilitation of Landfill Sites in Malaysia. In Technical Guideline for Sanitary Landfill, Design and Operation, Revised Draft; Final Report; Japan International Coorperation Agency: Tokyo, Japan, 2004; Volume 5, p. 126.

63. Jain, P.; Townsend, T.G.; Tolaymat, T.M. Steady-state design of vertical wells for liquids addition at bioreactor landfills. Waste Manag. 2010, 30, 2022-2029. [CrossRef] [PubMed]

64. Townsend, T.G. Leachate Recycle at Solid Waste Landfills Using Horizontal Injection. Ph.D. Thesis, University of Florida, Gainesville, FL, USA, 1995.

65. Jain, P.; Powell, J.; Townsend, T.G.; Reinhart, D.R. Estimating the hydraulic conductivity of landfilled municipal solid waste using the borehole permeameter test. J. Environ. Eng. 2006, 132, 645-652. [CrossRef]

66. Townsend, T.G.; Miller, W.L.; Earle, J.F.K. Leachate-recycle infiltration ponds. J. Environ. Eng. 1995, 121, 465-471. [CrossRef]

67. Xu, Q.; Kim, H.; Jain, P.; Townsend, T.G. Hydrologic evaluation of landfill performance (HELP) modeling in bioreactor landfill design and permitting. J. Mater. Cycles Waste Manag. 2012, 14, 38-46. [CrossRef]

68. The World Bank. Guidance Fact Sheet: Landfill Design. p. 6. Available online: http://siteresources. worldbank.org/INTCARBONFINANCE/Resources/MSW_SCS_FactSheet_Landfill_Design_Final.pdf (accessed on 8 August 2017).

69. Soil Water Content. Chapter 3. Available online: http://www.cfr.washington.edu/Classes.esrm.410/ Moisture.htm (accessed on 10 July 2017).

70. McEnroe, B.M. Maximum Saturated Depth over Landfill Liner. University of Kansas ASCE. J. Environ. Eng. 1993, 119, 262-270. [CrossRef]

(C) 2018 by the authors. Licensee MDPI, Basel, Switzerland. This article is an open access article distributed under the terms and conditions of the Creative Commons Attribution (CC BY) license (http:/ / creativecommons.org/licenses/by/4.0/). 